\title{
Age and Tectonic Significance of Volcanic Rocks in the Northern Los Angeles Basin, California
}

By Thane H. McCulloh, Robert J. Fleck, Rodger E. Denison, Larry A. Beyer, and Richard G. Stanley

Volcanic rocks in the eastern Santa Monica Mountains dated at $17.4 \mathrm{Ma}$ by argon isotopes and by strontium isotope ratios of interbedded fossil carbonates appear to be an early expression of deep crustal magmatism accompanying the earliest extensional tectonism associated with rifting in the Los Angeles Basin

Professional Paper 1669 


\title{
U.S. Department of the Interior \\ Gale A. Norton, Secretary
}

\author{
U.S. Geological Survey \\ Charles G. Groat, Director
}

Any use of trade, product, or firm names in this publication

is for descriptive purposes only and does not imply endorsement

by the U.S. Government.

United States Government Printing Office: 2002

For additional copies please contact:

USGS Information Services

Box 25286

Denver, CO 80225

This report and any updates to it are available at http://geopubs.wr.usgs.gov/prof-paper/pp1669/

Additional USGS publications can be found at http://geology.usgs.gov/products.html

For more information about the USGS and its products:

Telephone: 1-888-ASK-USGS (1-888-275-8747)

World Wide Web: http://www.usgs.gov/

Text edited by Peter H. Stauffer

Layout and design by Stephen L. Scott

Manuscript approved for publication, September 19, 2002

Cataloging-in-Publication data is on file with the Library of Congress

FRONT COVER

Mapped outcrops and known and inferred subsurface occurrences of Miocene volcanic rocks (orange colors), principal faults, and important drill holes (dots) draped on a shaded relief map of the study area. Geology and drill holes adapted from figure 1, p. 3.

(Shaded relief base is digital elevation model, using 30-meter cell size, from the U.S. Geological Survey National Elevation Dataset (NED). Topography has vertical exaggeration of $x 2$ and sun illumination from azimuth $315^{\circ}$ and elevation $45^{\circ}$. For more information on the NED, see http://gisdata.usgs.gov/ned/.) 


\section{CONTENTS}

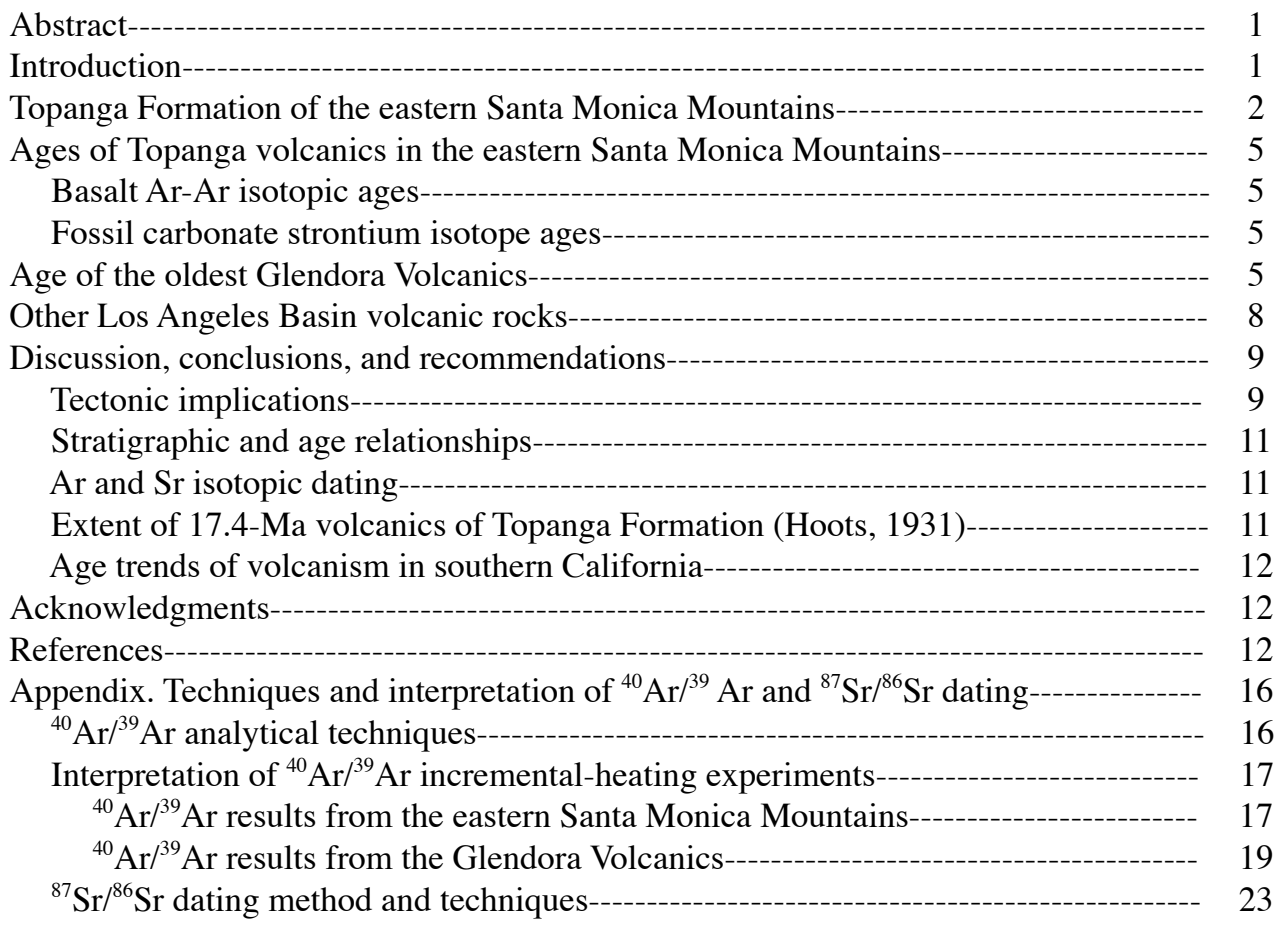

\section{FIGURES}

1. Map showing outcrops and subsurface occurrence of Miocene volcanic rocks within the Los Angeles Basin and around its perimeter

2. Geologic map of the eastern Santa Monica Mountains showing Topanga Formation (Hoots,1931), volcanic outcrops, and other features-

3. Plot of strontium isotope results from table 2 showing ages derived from curve of ${ }^{87} \mathrm{Sr} /{ }^{86} \mathrm{Sr}$ variation in seawater for part of the Miocene-

4. Chronological chart of Miocene volcanic rocks in and around the Los Angeles Basin-

5. Diagrams of the ${ }^{40} \mathrm{Ar} /{ }^{39} \mathrm{Ar}$ age spectrum and $\mathrm{Cl} / \mathrm{K}$ ratio from incremental heating of basalt samples $\mathrm{A}, \mathrm{B}$, and $\mathrm{C}$ from the Topanga Formation (Hoots, 1931) in the eastern Santa Monica Mountains

6. Diagrams of the ${ }^{40} \mathrm{Ar} /{ }^{39} \mathrm{Ar}$ age spectrum, $\mathrm{Cl} / \mathrm{K}$ ratio, and inverse isochron from incremental heating of

Glendora Volcanics samples GV-9 and GV-12

7. Diagrams of the ${ }^{40} \mathrm{Ar} /{ }^{39} \mathrm{Ar}$ age spectrum, $\mathrm{Cl} / \mathrm{K}$ ratio, and inverse isochron from incremental heating of Glendora Volcanics samples GV-17 and GV-18-

\section{TABLES}

1. Locations and ${ }^{40} \mathrm{Ar} /{ }^{39} \mathrm{Ar}$ ages of volcanic rock samples from the the Topanga Formation (Hoots, 1931) in the eastern Santa Monica Mountains and from the Glendora Volcanics in the San Jose Hills, California-

2. Locations, analytical results, and derived ${ }^{87} \mathrm{Sr} /{ }^{86} \mathrm{Sr}$ ages of fossil carbonate samples from the Topanga Formation (Hoots, 1931) of the eastern Santa Monica Mountains and the Topanga Formation type area, California---

3. Incremental heating ${ }^{40} \mathrm{Ar} /{ }^{39} \mathrm{Ar}$ ages of volcanic rocks of the Topanga Formation (Hoots, 1931) from the eastern Santa Monica Mountains and Glendora Volcanics, California- 


\title{
Age and Tectonic Significance of Volcanic Rocks in the Northern Los Angeles Basin, California
}

\author{
By Thane H. McCulloh ${ }^{1}$, Robert J. Fleck ${ }^{2}$, Rodger E. Denison ${ }^{3}$, Larry A. \\ Beyer $^{2}$, and Richard G. Stanley ${ }^{2}$
}

\section{Abstract}

Volcanic rocks, mostly basalts and some andesites, are interbedded with middle Miocene strata and are overlain by younger rocks throughout the greater part of the Los Angeles Basin, California. Roughly correlative flows, previously dated radiometrically (or paleontologically) at about 16.4 to 10.7 Ma, crop out in five separate regions around the basin perimeter. Los Angeles Basin volcanic rocks have special meaning because they offer clues to tectonomagmatic events associated with onset of clockwise transrotation of the western Transverse Ranges region and to the timing and locus of the initial basin opening.

Whole-rock ${ }^{40} \mathrm{Ar} /{ }^{39} \mathrm{Ar}$ dating of near-tholeiitic olivine basalts of the Topanga Formation (Hoots, 1931) from three sites in the easternmost Santa Monica Mountains, combined with ${ }^{87} \mathrm{Sr} /{ }^{86} \mathrm{Sr}$ dating of fossil carbonates from interstratified marine beds at nine sites, establish a new age of 17.4 Ma for these oldest known Topanga-age volcanics of the Los Angeles Basin. We also record three new ${ }^{40} \mathrm{Ar} /{ }^{39} \mathrm{Ar}$ ages $(15.3$ $\mathrm{Ma}$ ) from andesitic flows of the lower Glendora Volcanics at the northeast edge of the basin, $70 \mathrm{~km}$ east of the Santa Monica Mountains. A whole-rock determination of 17.2 \pm 0.5 Ma for nearby altered olivine basalt in the unfossiliferous Glendora volcanic sequence is questionable because of a complex ${ }^{40} \mathrm{Ar} /{ }^{39} \mathrm{Ar}$ age spectrum suggestive of ${ }^{39} \mathrm{Ar}$ recoil, but it may indicate an older volcanic unit in this eastern area.

We hypothesize that the 17.4-Ma volcanics in the eastern Santa Monica Mountains are an early expression of deep crustal magmatism accompanying the earliest extensional tectonism associated with rifting. The extremely thick younger volcanic pile in the western and central parts of the range may suggest that this early igneous activity in the eastern area was premonitory. Paleomagnetic declination data are needed to determine the pre-transrotational orientation of the eastern Santa Monica Mountains volcanic sequence. The new age determinations do not yield unequivocal support for either of two proposed explanations of possible age trends of

\footnotetext{
17136 Aberdeen Avenue, Dallas, Texas 75230

${ }^{2}$ U.S. Geological Survey, 345 Middlefield Road, Menlo Park, California 94025

${ }^{3}$ Department of Geosciences, University of Texas at Dallas, P.O. Box 830688, Richardson, Texas 75083-0688
}

Miocene volcanic rocks in southern California but underscore the need for further work.

\section{Introduction}

Deformed middle Tertiary extrusive volcanic rocks with locally associated or separate shallow intrusives are a widespread though volumetrically minor constituent of the Cenozoic stratal sequences in parts of coastal southern California and the California Continental Borderland. Exposures of such volcanic rocks extend for more than $400 \mathrm{~km}$ along the coast from Point Arguello southeast through the southern part of the western Transverse Ranges Province to the Los Angeles Basin and Continental Borderland and into coastal Baja California. Tectonically important because of constraints they impose on the nature and timing of major middle Tertiary crustal rearrangements, these rocks represent multiple separate volcanic fields that were fed from numerous independent eruptive or intrusive centers, many of them now buried or submerged (Shelton, 1955; Crouch, 1981, p. 204-205; Vedder, 1987; Legg, 1991, p. 294-295).

The ages of previously dated volcanic rocks in this region range between extremes of $4.36 \pm 0.8 \mathrm{Ma}$ for alkalic basalt at Northeast Bank (Hawkins and others, 1971) and 19.1 \pm 0.7 Ma for shallow hypabyssal granodioritic intrusives on Santa Catalina Island (Forman, 1970, table 1; Vedder

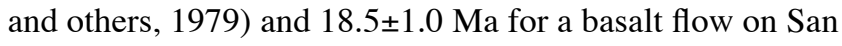
Miguel Island (Luyendyk and others, 1998). However, the great majority of dated rocks fall in a narrow range of 16$15 \mathrm{Ma}$ (with noteworthy outliers at 17.7 Ma and 11.0 Ma) (Turner, 1970; Turner and Campbell, 1979; Dickinson, 1997, table 2; Nourse and others, 1998; Luyendyk and others, 1998).

Hypotheses or explanations advanced to account for the nature, timing, and locations of middle Tertiary volcanism in coastal southern California, including the Los Angeles Basin, appeal to ridge-trench interactions associated more or less closely with the partial subduction of the Monterey and Arguello microplates beneath North America and their subsequent capture by the Pacific plate (Atwater, 1989; Severinghaus and Atwater, 1990; Nicholson and others, 1994; Atwater and Stock, 1998, p. 392-395). Results reported here do not support an appealing hypothesis (Luyendyk and others, 1998, fig. 3), based on published data from the coastal region south 
of the southern Coast Ranges, that suggests a systematic trend from oldest in the west (originally south, prior to transrotation) to youngest in the east (originally north).

Middle Tertiary volcanic rocks are mostly flows, some subaerial but many submarine. Hypabyssal intrusives and tuffs, breccias, and other pyroclastic or volcanogenic sediments occur but are subordinate. Rhyolites and dacites are widespread but relatively rare and tend to be among the younger units. The most abundant rocks are basaltic andesites and alkalic basalts in a calc-alkaline magma series that borders on tholeiitic basalt (Shelton, 1955; Eaton, 1958; Crowe and others, 1976; Higgins, 1976; Weigand, 1982; Johnson and O'Neil, 1984, tables 1 and 2; Weigand and Savage, 1993; Weigand and others, 1998).

Miocene lavas and fragmental volcanic rocks intercalated with mostly marine clastic strata, together with local hypabyssal intrusives, crop out discontinuously around the perimeter of the Los Angeles Basin (Hoots, 1931; Woodring and others, 1946; Shelton, 1955; Yerkes, 1957; Vedder and others, 1957, Dibblee, 1982; Conrad and Ehlig, 1983). Correlative volcanic units occur in drill holes within the basin beneath variable thicknesses of marine clastic strata (White, 1952; Eaton, 1958; Yerkes and others, 1965, West and Redin, 1990; West and Redin, 1991; Wright, 1991, fig. 5; Blake, 1991, McCulloh and others, 2001). Figure 1 shows the distribution of both outcrops and drill-hole occurrences compiled from available sources, together with our best estimates of present and likely original distributional limits. Locations of critical drill holes that provide evidence for the areas where volcanics are absent are not shown because they are published elsewhere (Eaton, 1958; Yerkes and others, 1965; Wright, 1991, figs. 4, 5). We draw attention especially to the absence of evidence for volcanic rocks in a large subsurface region west of long. $118^{\circ} \mathrm{W}$, north of lat. $34^{\circ} \mathrm{N}$, and south of the Santa Monica-HollywoodRaymond Fault Zone. Possible meanings for this absence will be discussed below. Outlined on figure 1 is an area in the easternmost Santa Monica Mountains where samples, whose isotopic ages are reported here, were collected - basalts (three localities) and marine carbonate fossils from beds above, within, and beneath submarine flows (nine localities). Also shown are outcrops of Glendora Volcanics in the northeastern San Jose Hills. Isotopic ages of four samples from the basal and lower flows of this sequence are also reported here.

\section{Topanga Formation of the Eastern Santa Monica Mountains}

The Topanga Formation is a Miocene mixed sedimentary and volcanic unit in the Los Angeles region first defined by Hoots (1931). The thickness of the formation (Hoots, 1931) in the easternmost Santa Monica Mountains probably exceeds $1,650 \mathrm{~m}$. Its base is an erosional unconformity. In the western part of this area, marine basal Topanga sandstones rest on uppermost Paleocene conglomerate and sandstone (Colburn and Novak, 1989, figs. 3, 8) that, in turn, overlie coarse unfossiliferous Upper Cretaceous clastic strata (fig. 2). East of Cahuenga Pass and the northwest-plunging syncline that parallels the pass, either basalt or nonmarine sandstone rests directly on Lower Cretaceous granodiorite or quartz diorite (Hoots, 1931; Miller and Morton, 1980), all pre-Miocene strata and some older Miocene units present in the western and central Santa Monica Mountains having been overlapped (Dibblee, 1989, fig. 7).

The Topanga Formation (Hoots, 1931) is divisible, both east and west of Cahuenga Pass, into three parts: (1) A basal marine conglomeratic sandstone that ranges in thickness from zero in the east to $100 \mathrm{~m}$ in the west, (2) a dominantly basaltic middle unit of multiple submarine lava flows and tuffs as much as about $670 \mathrm{~m}$ thick, and (3) an upper unit of sedimentary breccia, conglomerate, sandstone, and siltstone that probably exceeds $1,000 \mathrm{~m}$ in thickness and locally contains marine fossils. Fossiliferous calcareous sandstones, calcarenites, and coquinoid limestones are interbedded with the basalt flows and also occur beneath and above the flows. The locations of basalt samples used for Ar-Ar dating and of fossils analyzed for ${ }^{87} \mathrm{Sr} /{ }^{86} \mathrm{Sr}$ are shown on figure 2 . The stratigraphically highest of these (locality b) is identical to UCLA locality 2303, which yielded a fauna identified as "Middle Miocene...Temblor" on the basis mainly of the presence of Lyropecten crassicardo and Turritella ocoyana (W. P. Popenoe in Neuerburg, 1953, p. 23) and is younger than any of the nearby lavas. The stratigraphically lowest site (locality f) underlies all of the volcanic units and is virtually at the basal unconformity.

A hiatus and angular erosional unconformity separates the Topanga Formation from the overlying deep marine Miocene Modelo Formation (Hoots, 1931). Deposited on a submarine fan complex, the Modelo consists of shale and sandstone, clastic detritus derived from erosion of mountainous terrain presently to the north of the Los Angeles Basin (Sullwold, 1960; Redin, 1991; Dibblee, 1991). The area of Modelo Formation mapped at the easternmost end of the Hollywood Hills as resting unconformably on Topanga Formation and granodiorite (Hoots, 1931, plate 16; Dibblee, 1989, 1991) was considered part of the "Topanga Formation" by Lamar (1970). Foraminiferal faunas from several localities in that area belong in the lowermost Mohnian benthic foraminiferal stage (Lamar, 1970, p. 19) and therefore fit better both faunally and lithologically with the Modelo (or Puente) Formation (Blake, 1991). We endorse the assignment of these rocks to the Modelo Formation, which reinforces our judgement of the prominence of the pre-Modelo erosional break and angular unconformity.

The great thickness and stratigraphic complexities of the sequence that Kew (1923) originally defined faunally and named "Topanga Formation" led later workers to subdivide his "Formation" into three formations (Durell, 1954) and subordinate members and to elevate the name Topanga to group rank (Yerkes and Campbell, 1979, p. E13-E24, fig. 3). The site of the well-known Topanga Canyon molluscan fauna (Arnold, 1907, p. 525-526; Kew, 1923, p. 48), now in the type section of the lowest formational unit of the Topanga Group in the central Santa Monica Mountains, the Topanga Canyon 
Formation (Yerkes and Campbell, 1979), is located about 22 $\mathrm{km}$ west of our map area (fig.2). Further elaborations of the subdivisions of the Topanga Group emphasize their facies equivalency (for example, Fritsche, 1993, fig. 4). The base of the very thick Conejo Volcanics (middle formational unit of the Topanga Group in the central Santa Monica Mountains) is no older than upper Relizian (Yerkes and Campbell, 1979, p. E21), or about $16 \mathrm{Ma}$ according to the most recent pertinent chronostratigraphic framework (Barron and Isaacs, 2001, fig. 22.1). This foraminifer-based age essentially agrees with the 15.9 \pm 0.8 -Ma K-Ar age of plagioclase from basalt " $150 \mathrm{ft}$ above base Conejo Volcanics" (Turner and Campbell, 1979, p. E21, table 1), with recalculation using current decay constants. We are not yet prepared to say that the stratigraphic nomenclature developed in the western and central Santa Monica Mountains is applicable directly to rocks of the east-

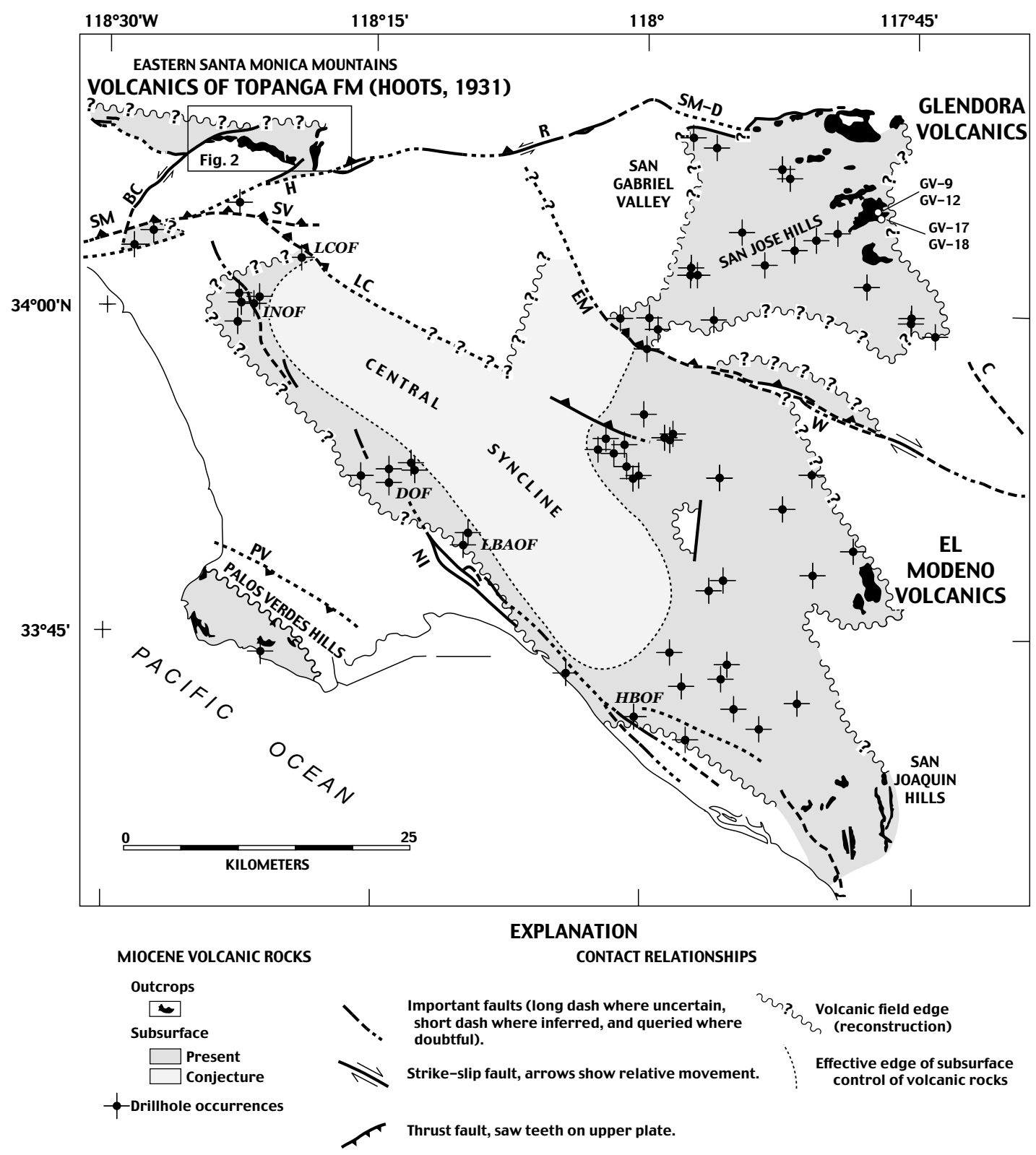

Figure 1.-Outcrops and subsurface occurrences of Miocene volcanic rocks located within the Los Angeles Basin and around its perimeter. Locations of drill holes (without volcanics) drilled to pre-volcanic sequences that help to define the limits of the subsurface areas of volcanic rocks are published elsewhere (Wright, 1991, figs. 4, 5). Fault abbreviations: BC, Benedict Canyon; C, Chino; EM, East Montebello; H, Hollywood; LC, Las Cienegas; N-I, Newport-Inglewood; PV, Palos Verdes; R, Raymond; SM, Santa Monica; SM-D, Sierra MadreDuarte; SV, San Vicente; W, Whittier. Five oil fields mentioned in the text are labeled: DOF, Dominguez; HBOF, Huntington Beach; INOF, Inglewood; LCOF, Las Cienegas; LBAOF, Long Beach Airport. Inset frame shows area of figure 2. Locations of new Ar-Ar dated Glendora Volcanicsamples are also shown. 


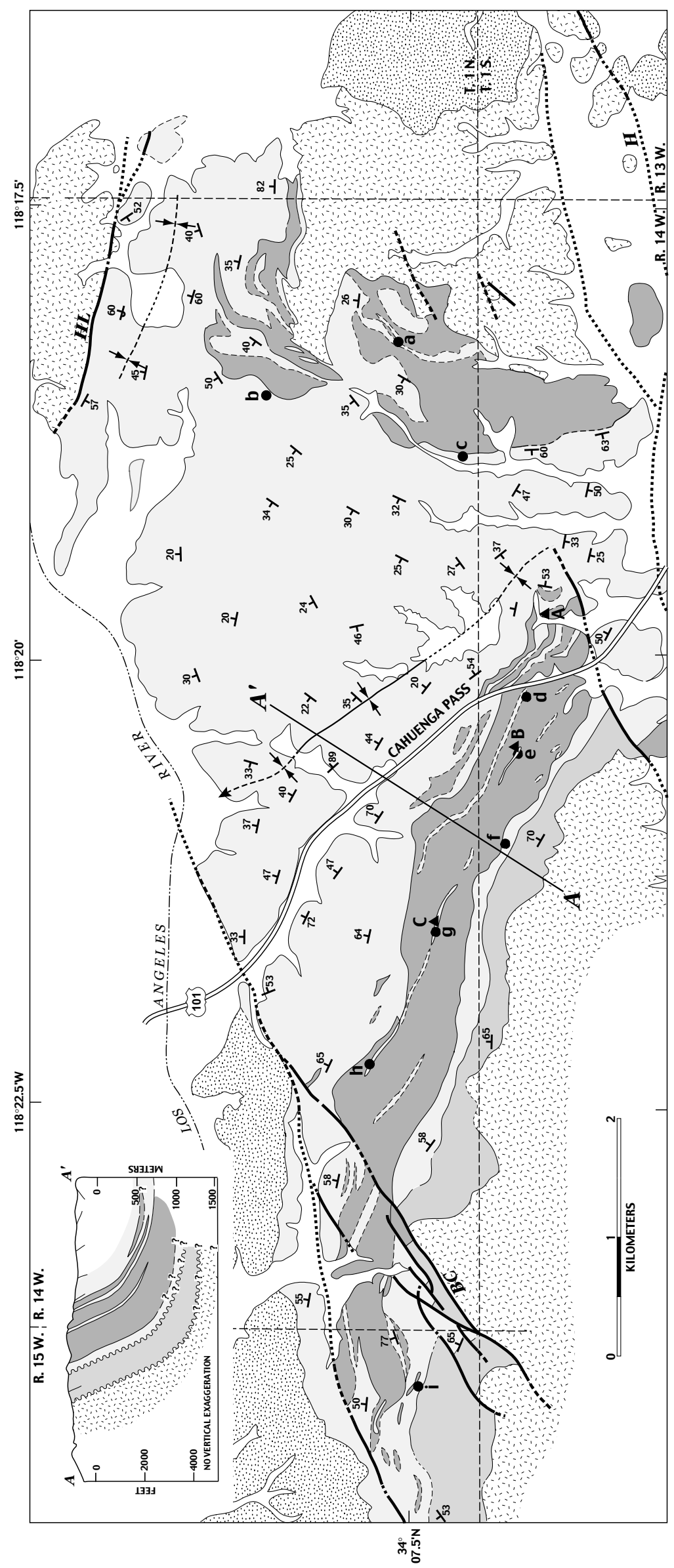

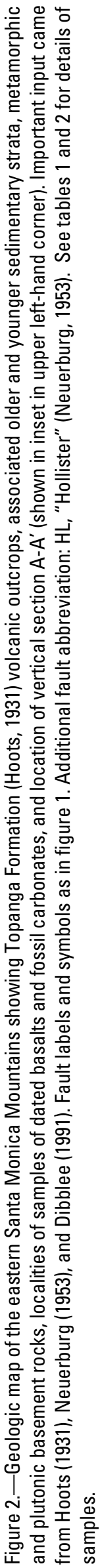


ernmost part of the range, and therefore we prefer to adhere to the original assignments (Hoots, 1931).

\section{Ages of Topanga Volcanics in the Eastern Santa Monica Mountains}

Fossils in strata underlying and interbedded with volcanics of the Topanga Formation (Hoots, 1931) in the eastern Santa Monica Mountains are largely littoral or shallow neritic forms that generally are only crudely diagnostic of age. An occurrence of middle Relizian and younger (16.4 Ma and younger) Lyropecten crassicardo in one assemblage from the north slope of Mount Hollywood (UCLA locality 2302 reported in Neuerburg, 1953, table 3) is clouded by the associated occurrence of the early Miocene "Lyropecten cf. miguelensis" (see Vedder, 1973, fig. 9). Other fossil assemblages are either not precisely age diagnostic or from beds younger than any nearby lavas. Recognizing the importance of better constrained ages for the volcanics and related sedimentary strata, we have turned to nonpaleontologic methods.

\section{Basalt Ar-Ar Isotopic Ages}

Samples of medium- to fine-grained basalt were collected from outcrops of the middle part of the Topanga Formation (Hoots, 1931) in the eastern Santa Monica Mountains west of the Cahuenga Pass syncline, spanning a distance along strike of about $4 \mathrm{~km}$. After petrographic evaluation for presence of volcanic glass or alteration products, three of these were selected for age determination by the ${ }^{40} \mathrm{Ar} /{ }^{39} \mathrm{Ar}$ incremental-heating method. These three samples are all from flows roughly at the same stratigraphic horizon in the middle part of the volcanic sequence; the easternmost sample is from near the syncline axis (fig. 2). Analytical data, procedures, and interpretations of age spectra are presented in the appendix. ${ }^{40} \mathrm{Ar} /{ }^{39} \mathrm{Ar}$ age spectra obtained from all three samples indicate the presence of excess ${ }^{40} \mathrm{Ar}$ in the rocks, requiring identification of increments minimally affected by this interference (see appendix, table 3, fig. 5). Ages of all three samples are the same within analytical uncertainties and have a weighted mean age of $17.38 \pm 0.08 \mathrm{Ma}$ (table 1).

This mean age must be considered a maximum for the time of lava extrusion because of the evidence of excess ${ }^{40}$ Ar. Nevertheless, the close agreement of the minimum ages defined by the age spectra suggests that their mean may closely represent the eruption age. An early Miocene age approximately equivalent to the latest Saucesian benthic foraminiferal stage (Barron and Isaacs, 2001) is thus indicated, an age about $1.5 \mathrm{~m}$.y. older than the oldest Conejo Volcanics of the central Santa Monica Mountains (Turner and Campbell, 1979).

\section{Fossil Carbonate Strontium Isotopic Ages}

Littoral to shallow shelf marine fossils are widespread, fairly abundant, and generally well preserved within the
Topanga Formation (Hoots, 1931) sequence that contains basalt flows in the eastern Santa Monica Mountains. Analyses of the strontium isotopes in these fossils can be used to assign numeric ages. The Oligocene and earlier Miocene are particularly well suited for stratigraphic applications of the technique because the ${ }^{87} \mathrm{Sr} /{ }^{86} \mathrm{Sr}$ ratio in seawater increased rapidly and monotonically during those time intervals. The ${ }^{87} \mathrm{Sr} /{ }^{86} \mathrm{Sr}$ ratio of a fossil can be used to assign an age and probable error by comparison with an established curve of time versus the seawater ${ }^{87} \mathrm{Sr} /{ }^{86} \mathrm{Sr}$ value (for example, McArthur and others, 2001).

Fossil shells from nine sites along nearly $9 \mathrm{~km}$ of outcrop strike in the eastern Santa Monica Mountains were selected and prepared for analysis. Fossil type and appearance were the basis for field selection. Laboratory selection, preparation, and analytical methods are outlined in the appendix. The results of the isotopic and chemical analyses, and assigned ages, are shown in table 2. Results of analyses of three fossils from the type Topanga Canyon Formation are given for comparison. A nearshore but open marine environment is suggested by the rare but widespread occurrences of pectenids (Neuerburg, 1953).

Eight of the samples from fossils associated directly with the basalts yielded very similar isotope ratios; their mean ${ }^{87} \mathrm{Sr} /{ }^{86} \mathrm{Sr}$ is $0.708654 \pm 16$, equivalent to an age of $17.3 \pm 0.3 \mathrm{Ma}$ (McArthur and others, 2001).

Two sparry carbonate samples have ratios that are above and below the mean of consistent ratios, giving important guides to the interpretation of the results. Trace elements from both samples show that they recrystallized in the presence of imported components. The sparry gastropod(?) from strata interbedded with basalt at locality d (fig. 2) yielded an ${ }^{87} \mathrm{Sr} /{ }^{86} \mathrm{Sr}$ value that is lower than the mean of the best shell material, suggesting that basalt-derived solutes contributed low-ratio strontium during replacement. The spar-replaced oyster fraction from locality i (fig. 2) yielded a ratio higher than the mean, showing that the origin of the pore fluids and their migration in this sequence was complicated. Nonetheless, these two samples, despite their complete recrystallization and elevated $\mathrm{Mn}$ and Fe contents, yielded ${ }^{87} \mathrm{Sr} /{ }^{86} \mathrm{Sr}$ ratios that are not profoundly different from the mean of samples judged to be minimally altered.

The very close agreement between the age of $17.38 \pm 0.08$ Ma determined by Ar-Ar analyses of basalts of the eastern Santa Monica Mountains and the age of 17.3 \pm 0.3 Ma determined by strontium isotopic dating of directly associated fossils is shown in figure 3 . The importance of the age is discussed in the concluding section.

\section{Age of the Oldest Glendora Volcanics}

The type area of the Glendora Volcanics (Shelton, 1946; 1955; Nourse and others, 1998) is at the northeastern edge of the Los Angeles Basin, about $70 \mathrm{~km}$ directly east of the eastern end of the Santa Monica Mountains. The overall thickness of volcanic units is variable, partly because of erosion, 
Table 1.-Locations and ${ }^{40} \mathrm{Ar} /{ }^{39} \mathrm{Ar}$ ages of volcanic rock samples from the Topanga Formation (Hoots, 1931) in the eastern Santa Monica Mountains and from the Glendora Volcanics in the San Jose Hills, California.

\begin{tabular}{|c|c|c|c|c|}
\hline $\begin{array}{l}\text { Map } \\
\text { Symbol } \\
\text { (figs. 1 } \\
\text { and 6) }\end{array}$ & $\begin{array}{l}\text { Latitude (N) } \\
\text { Longitude (W) } \\
\text { (degrees) }\end{array}$ & $\begin{array}{l}\text { Total } \\
\text { Gas } \\
\text { Age } \\
\text { (Ma) }\end{array}$ & $\begin{array}{l}\text { Best } \\
\text { Estimate } \\
\text { Age } \\
(\mathrm{Ma})^{*}\end{array}$ & Comments \\
\hline A & $\begin{array}{c}34.114 \\
118.3294\end{array}$ & $20.7 \pm 0.6$ & $17.38 \pm 0.12$ & Olivine basalt; middle part of multiple flows. \\
\hline B & $\begin{array}{c}34.1161 \\
118.3414\end{array}$ & $18.7 \pm 0.6$ & $17.38 \pm 0.11$ & Olivine basalt; middle part of multiple flows. \\
\hline C & $\begin{array}{r}34.1283 \\
118.3708\end{array}$ & $19.8 \pm 0.6$ & $17.27 \pm 0.45$ & Olivine basalt; middle part of multiple flows. \\
\hline GV-9 & $\begin{array}{r}34.0796 \\
117.7889\end{array}$ & $15.4 \pm 0.5$ & $15.08 \pm 0.11$ & $\begin{array}{l}\text { Andesite; plagioclase separate; within } \\
\text { middle part of "hypersthene andesite" unit } \\
\text { of Shelton (1955). }\end{array}$ \\
\hline GV-12 & $\begin{array}{r}34.0813 \\
117.7831\end{array}$ & $15.4 \pm 0.5$ & $15.32 \pm 0.16$ & $\begin{array}{l}\text { Andesite; plagioclase separate; at base of } \\
\text { "hypersthene andesite" unit of Shelton } \\
\text { (1955). }\end{array}$ \\
\hline GV-17 & $\begin{array}{r}34.0759 \\
117.7837\end{array}$ & $17.2 \pm 0.5$ & $17.2 \pm 0.5$ & Basalt, iddingsite-bearing. \\
\hline GV-18 & $\begin{array}{r}34.0746 \\
117.7857\end{array}$ & $15.2 \pm 0.4$ & $15.28 \pm 0.05$ & $\begin{array}{l}\text { Andesite; plagioclase separate; near base } \\
\text { of "hypersthene andesite" unit of Shelton } \\
\text { (1955). }\end{array}$ \\
\hline
\end{tabular}

* See appendix for analytical details, including interpretations of complex Ar release patterns.

and is as much as $914 \mathrm{~m}$ in drill holes west of the principal outcrops (fig. 1). Nourse and others (1998) reported ${ }^{40} \mathrm{Ar} /{ }^{39} \mathrm{Ar}$ ages of $16.3 \pm 1$ and $15.9 \pm 0.3 \mathrm{Ma}$ for these volcanic rocks, roughly consistent with paleontologic ages of overlying Relizian marine strata (West and Redin, 1991; McCulloh and others, 2001, p. 12-13, appendix 2).

Four samples of the Glendora Volcanics were collected within an area of $<0.6 \mathrm{~km}^{2}$ in the easternmost part of the San Jose Hills (Shelton, 1955, plate 1). On the basis of Shelton's (1955) geologic mapping and our own reconnaissance field studies, all four samples appear to represent the lower part of the folded and faulted volcanic sequence, where the flows rest either on granitoid rocks of the basement complex or on 27.6Ma intrusive dacite (Nourse and others, 1998; McCulloh and others, 2001). Three of the analyzed samples are of andesitic composition. A fourth sample of basaltic composition, GV17 , was collected from a unit of interstratified basalt, sandstone, and conglomerate exposed in roadcuts that postdate the mapping of Shelton (1955). The basaltic and andesitic units are separated by a fault of undetermined displacement, leaving their relative stratigraphic positions uncertain. The
${ }^{40} \mathrm{Ar} /{ }^{39} \mathrm{Ar}$ results and interpretations, summarized in table 1 , are presented in the appendix (table 3, figs. 6, 7).

Andesites within the lower part of the Glendora Volcanics (samples GV-9, GV-12, and GV-18) yielded ages from 15.4 to $15.1 \mathrm{Ma}$ with uncertainties of 0.05 to $0.16 \mathrm{Ma}$ $(1 \sigma)$. Although exact stratigraphic positions are difficult to ascertain, GV-12 and GV-18 appear to be near the base of the unit as mapped by Shelton (1955), whereas GV-9 was collected somewhat higher in the andesite. Although none of the age spectra is entirely undisturbed, the agreement of all andesite plateau ages within analytical error indicates a mean age of about $15.25 \pm 0.08 \mathrm{Ma}$. This compares to an age of $15.9 \pm 0.8 \mathrm{Ma}$ for the base of the Conejo Volcanics (Turner and Campbell, 1979, with recalculation using current decay constants). The age of the Glendora Volcanic andesite samples is close to the 15.7-Ma age of the Luisian-Relizian provincial foraminiferal stage boundary (Barron and Isaacs, 2001) and distinctly younger than the submarine basalts of the eastern Santa Monica Mountains (table 1).

The olivine-bearing basalt, sample GV-17 from a roadcut exposure $560 \mathrm{~m}$ northeast of GV-18, introduces uncertainty 


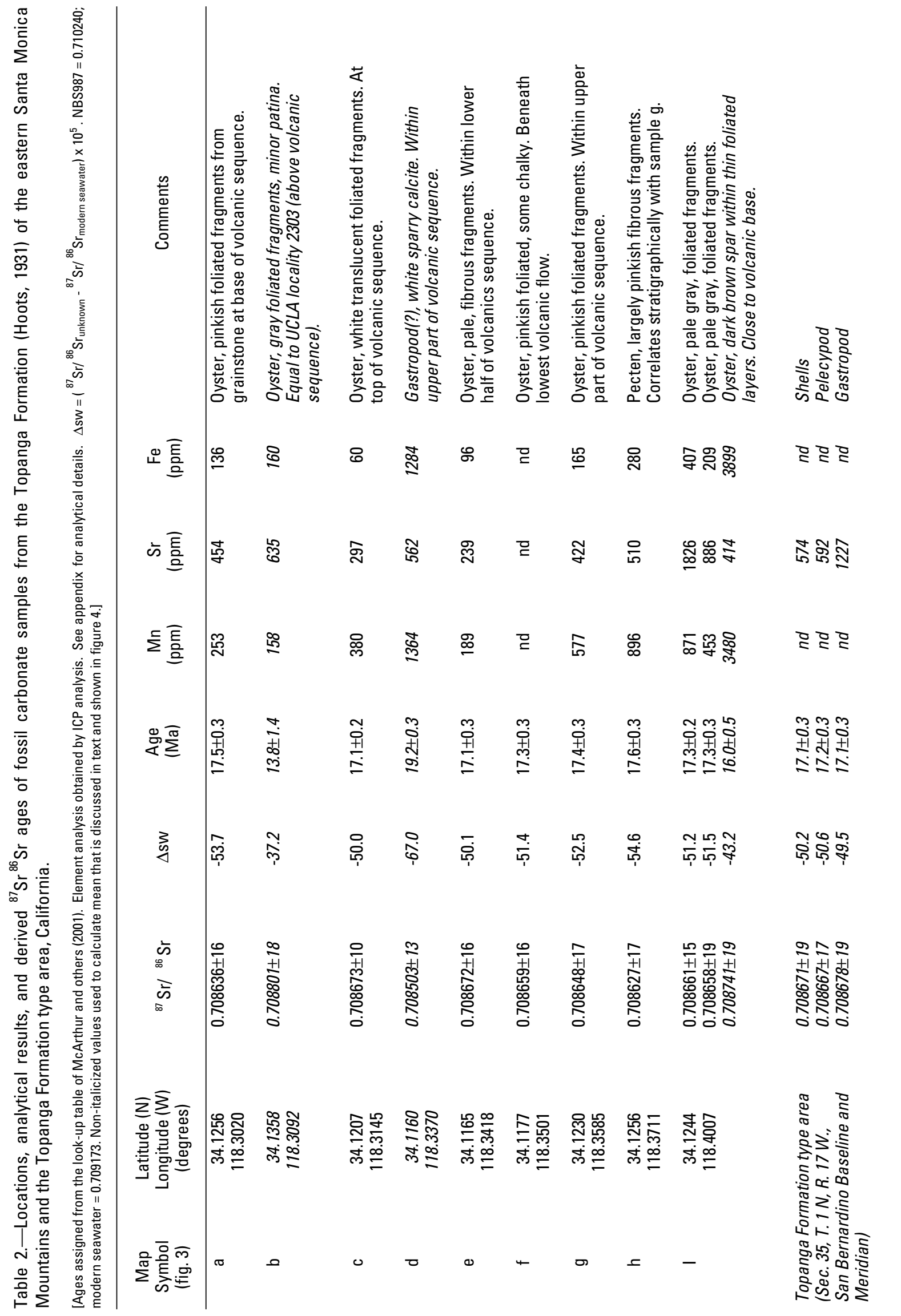


into the timing of initiation of volcanism near the northeastern edge of the Los Angeles Basin. This sample is from a sequence of basalt flows with intercalated lenses of unfossiliferous sandstone and conglomerate that crops out adjacent to an area mapped by Shelton (1955) as "basement complex". Incremental heating of this sparsely porphyritic basalt with its very fine grained groundmass yields a complex ${ }^{40} \mathrm{Ar} /{ }^{39} \mathrm{Ar}$ age spectrum suggestive of ${ }^{39} \mathrm{Ar}$ recoil. We consider the totalgas age of 17.2 $\pm 0.5 \mathrm{Ma}$ from this whole-rock sample to be the best estimate, but it may be erroneously old if some ${ }^{39} \mathrm{Ar}$ has been lost (appendix). Because the stratigraphic relationship between the sampled andesitic and basaltic strata is not conclusively known, the 17.2-Ma age of GV-17 cannot be discounted and may represent an older, and possibly separate, volcanic unit. On the basis of the age of $15.25 \pm 0.08 \mathrm{Ma}$ for the more abundant and widespread andesites, we consider the

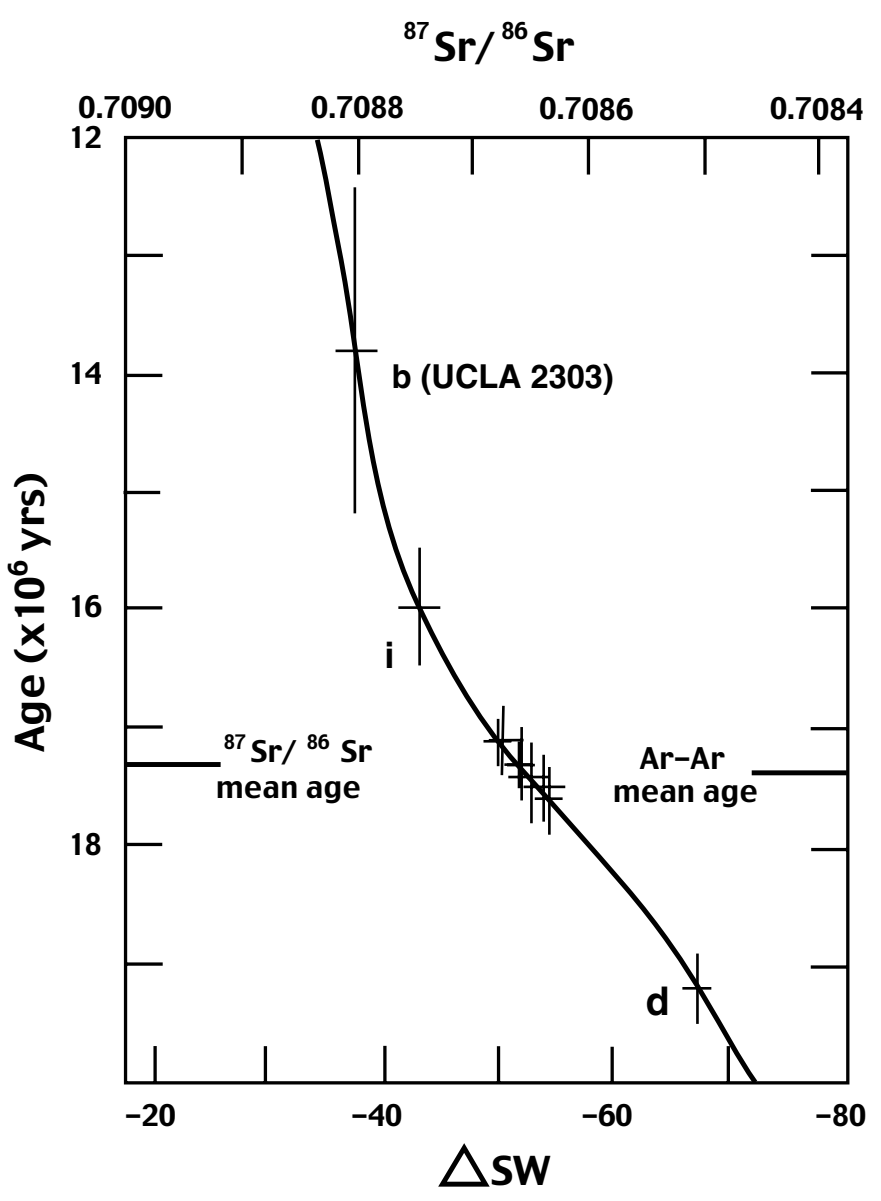

Figure 3.-Strontium isotope results from table 2 plotted on the curve of ${ }^{87} \mathrm{Sr} /{ }^{86} \mathrm{Sr}$ variation in seawater during part of the Miocene. The curve, from McArthur and others (2001), is based largely on results from deep-sea drilling samples. The cluster of eight samples from the eastern Santa Monica Mountains (fig. 2) yields a mean age of $17.3 \pm 0.3$ $\mathrm{Ma}$. The $17.38 \pm 0.08 \mathrm{Ma}$ weighted mean age from the Ar-Ar analyses is shown for comparison. Samples $d$ and $i$ have elevated $\mathrm{Mn}$ and $\mathrm{Fe}$ content (table 2) indicative of diagenetic alteration and isotopic exchange. Sample b is from a locality stratigraphically above the volcanic sequence. $\Delta \mathrm{sw}=\left({ }^{87} \mathrm{Sr} /{ }^{86} \mathrm{Sr}_{\text {unknown }}{ }^{87} \mathrm{Sr} /{ }^{86} \mathrm{Sr}_{\text {modern seawater }}\right) \times 10^{5}$. lower part of the Glendora Volcanics to be the same age as the middle part of the Conejo Volcanics and significantly younger than the volcanic rocks of the Topanga Formation (Hoots, 1931) in the easternmost Santa Monica Mountains. Further efforts are needed to evaluate the ages of other occurrences of basalt mapped as Glendora Volcanics, including those near Puddingstone Dam described as "pillow lava" by Shelton (1955, plate 1).

\section{Other Los Angeles Basin Volcanic Rocks}

No direct physical connection has been established, and none is believed to exist, between the Glendora Volcanics and the volcanics of the Topanga Formation (Hoots, 1931) of the eastern Santa Monica Mountains or the Conejo Volcanics farther west. Data from deep drill holes allow a western edge of the Glendora Volcanics to be mapped roughly coincident with longitude $118^{\circ} \mathrm{W}$. in the subsurface beneath the San Gabriel Valley and western Whittier Hills (McCulloh and others, 2001, fig. 6). Volcanic rocks are absent north and south of the Whittier Fault southeast of the Hollywood-Raymond Fault and west of approximate longitude $118^{\circ} \mathrm{W}$. The easterly pinchout of all units of the volcanics in the Santa Monica Mountains suggests that no direct connection ever existed. However, the great depth to the volcanic-equivalent horizon between the Hollywood and Las Cienegas Faults, and the dearth of drill holes deep enough to provide control, limits mapping except at the Las Cienegas oil field. There the volcanic-equivalent horizon is absent at the unconformity separating basement from uppermost Topanga Formation (Hoots, 1931) or Modelo equivalent strata (Mefford, 1970, plate III; Schneider and others, 1996, fig. 9). "Topanga volcanic rocks...entrained in the Las Cienegas fault" along the south flank of the anticlinal high (Tsutsumi and others, 2001, p. 464) are a questionable exception because they are merely tuffaceous sedimentary beds. Thus, for lack of control or because of either original absence or posteruption erosional removal, a large area of the northwestern flank of the basin is shown on figure 1 as lacking volcanics.

Volcanic rocks are present in the basin south of the Whittier Fault and east of about longitude $118^{\circ} \mathrm{W}$. Some of these clearly represent a continuation of the Glendora Volcanics, connecting through the Whittier Hills (with about $9 \mathrm{~km}$ of right strike slip across the Whittier Fault). Others may represent continuations of another possibly partly younger suite erupted from a separate center, the El Modeno volcanic center (Yerkes, 1957; Eaton, 1958; Turner, 1970; Luyendyk and others, 1998). Topanga Group strata are much too deep and (or) economically unpromising to have been drilled beneath the central synclinal trough of the basin, except at the northwestern and southeastern (up-plunge) ends. Therefore, neither the presence nor absence of volcanic rocks in this area can be demonstrated (fig. 1). Our map reflects the presence of volcanics at both ends and both flanks of the syncline and our judgement that these suggest their presence throughout the undrilled axial part. 
Volcanic rocks have been encountered in some deep drill holes along the Newport-Inglewood Fault Zone (White, 1952; Graves, 1954; Eaton, 1958; Harris, 1958; Wright, 1991, figs. 22, 25). Those at Inglewood oil field have been paleontologically dated as about 13.6 Ma to possibly 16.5 Ma (Castle and Yerkes, 1976, plate 1). The youngest of those at Dominguez oil field might be as young as $13 \mathrm{Ma}$ on the basis of published paleontological data (Graves, 1954). Basaltic lavas interbedded with unfossiliferous fine-grained sedimentary strata beneath the Long Beach Airport oil field are older than 13.5-Ma foraminiferal beds but are otherwise undated (Harris, 1958). Basalts and andesites in multiple wells at and around Huntington Beach oil field have been paleontologically zoned in the range from about $15 \mathrm{Ma}$ to questionably $16.5 \mathrm{Ma}$ (Eaton, 1958). Importantly, volcanic rocks drilled along the Newport-Inglewood Fault Zone are largely restricted to local fault blocks along the northeast side of the zone; on fault blocks southwest of the fault they occur only in limited areas at four restricted sites.

The subsurface occurrences at the southeast end of the volcanic field along the Newport-Inglewood Fault Zone probably merge with volcanics of the Topanga Formation studied in San Joaquin Hills outcrops (Vedder and others, 1957). Andesitic flow breccias there were dated radiometrically as 16.7 to $14.1 \mathrm{Ma}$ (Turner, 1970).

Altogether separate physically from all of the volcanics mentioned above is a field of more or less altered olivine basalts restricted to the Palos Verdes Hills and largely to their seaward flank. Those submarine basalts underlie or intertongue with basal Luisian and (or) Relizian strata of the Monterey Formation (Woodring and others, 1946; Eaton, 1958; Conrad and Ehlig, 1983). Although dated paleontologically at about $15.5 \mathrm{Ma}$, they have not been radiometrically dated. They thin and wedge out on the northeast flank of the Palos Verdes Hills between the Catalina Schist basement and the Luisian base of the Monterey Formation.

Figure 1 shows the locations of the various Los Angeles Basin area volcanics described above. The chronostratigraphic relations among them are summarized in figure 4. The northwestern and northern limits to the distribution of volcanics in the northwestern part of the basin are especially important for regional understanding. The thick and nearly continuous volcanic sequences present north of the Santa Monica-Hollywood Fault Zone, and the absence of such sequences to the south, requires explanation that has not been previously attempted.

\section{Discussion, Conclusions, and Recommendations}

The new age determinations reported here show that the oldest known Miocene volcanic rocks of the Los Angeles Basin crop out in the easternmost Santa Monica Mountains north of the Santa Monica-Hollywood Fault Zone. These rocks are olivine-bearing basalts that were erupted onto a shallow sea floor where subsidence equalled or outpaced a very rapid overall accumulation rate of more than $3.3 \mathrm{~mm} / \mathrm{yr}$. Both the whole rock ${ }^{40} \mathrm{Ar} /{ }^{39} \mathrm{Ar}$ ages and the fossil carbonate ${ }^{87} \mathrm{Sr} /{ }^{86} \mathrm{Sr}$ ages agree in assigning a 17.4-Ma age to these near-tholeiitic basalts. This age is $1.5 \mathrm{~m}$.y. older than the older dated part of the Conejo Volcanics in the western Santa Monica Mountains and among the oldest ages for Miocene volcanics of coastal southern California (fig. 4).

The new age determinations also indicate that andesitic rocks in the lower part of the Glendora Volcanics erupted at about 15.4 to $15.1 \mathrm{Ma}$ and are therefore about the same age or slightly younger than the lowest volcanic strata of the Conejo

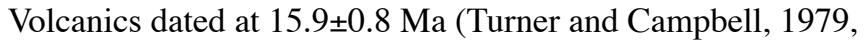
p. E21, with recalculation using current decay constants).

Furthermore, the andesites in the Glendora Volcanics area are clearly younger than the 17.4-Ma basalts in the eastern Santa Monica Mountains.

The significance of the age determination of $17.2 \pm 0.5$ Ma for basalt in the lower part of the Glendora Volcanics is uncertain. No fossil carbonate ${ }^{87} \mathrm{Sr} /{ }^{86} \mathrm{Sr}$ ages are obtainable for comparison with this age. As discussed in the appendix, it is unclear whether the 17.2-Ma age represents an older, previously unrecognized basaltic interval, or instead is erroneously too old owing to ${ }^{39} \mathrm{Ar}$ loss.

\section{Tectonic Implications}

Nearshore marine volcanics of the eastern Santa Monica Mountains are either the same age as the inferred time of onset of western Transverse Ranges clockwise transrotation (Luyendyk, 1990, fig. 3; Nicholson and others, 1994, fig. 3) or just slightly older (Hornafius and others, 1986, fig. 2; Dickinson, 1996, p. 14 and table 2). Their age therefore places a maximum limit on the time of initial opening of Los Angeles Basin (Bohannon and Geist, 1998, p. 785). At the time of eruption, the present roughly east-west strike of the volcanics must have been oriented in a different, pre-transrotational position, possibly roughly northeast-southwest.

The location of these oldest volcanics suggests a way to localize the initial extensional failure zone related to early stages of the clockwise tectonic rotation of the western Transverse Ranges. The starting position of this failure zone is imperfectly defined (Kamerling and Luyendyk, 1979; Hornafius and others, 1986; Crouch and Suppe, 1993; Nicholson and others, 1994). If the amount of clockwise rotation of the volcanics were firmly established, much of the present uncertainty about the locus of the northernmost end of the transrotational breakaway would vanish. Clarification of the most likely position and orientation of the zone of rifting responsible for the Miocene and later opening of the Los Angeles Basin would result. Paleomagnetic declination data are needed to firmly fix the pre-transrotational orientation of the eastern Santa Monica Mountains volcanic sequence. Such data should preferably differentiate between the limited area of volcanics northeast of the Cahuenga Pass syncline and the lava outcrops to the west. 


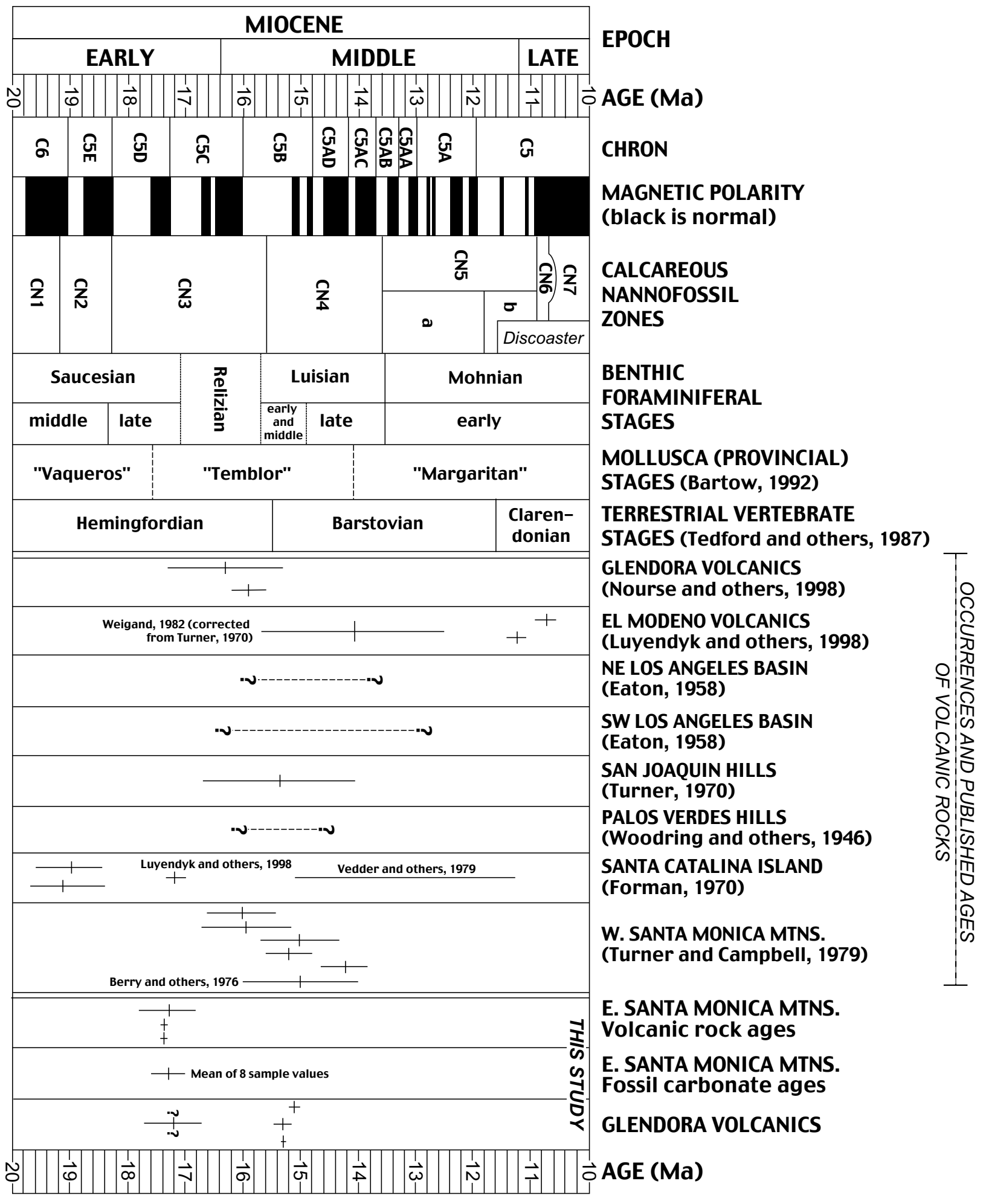

Figure 4.-Chronological chart of Miocene volcanic rocks in and around the Los Angeles Basin (including the western Santa Monica Mountains and Santa Catalina Island). Solid lines represent volcanic ages with uncertainties, while dashed lines represent less certain age ranges. Chronostratigraphic and biostratigraphic data are adapted from compilation of Barron and Isaacs (2001). 
Although we believe this study is a major step forward in understanding, much remains to be done. We hypothesize that the 17.4-Ma volcanic rocks of the Topanga Formation (Hoots, 1931) in the eastern Santa Monica Mountains are an early expression of deep crustal magmatism accompanying the earliest extensional tectonism associated with rifting. If further work confirms the questionable 17.2-Ma age of basalt at the base of the Glendora Volcanics, the evidence of early volcanism would be extended to the northeasternmost edge of the Los Angeles Basin. The absence in the eastern Santa Monica Mountains of volcanic rocks that are age equivalents of the extremely thick younger volcanic pile in the western and central parts of the range suggests that the early igneous activity in the eastern area was premonitory. Early cessation of that oldest volcanism may indicate a false start in that eastern area to the earliest phase of transrotational tectonism. Knowledge of the paleomagnetic declination in the 17.4-Ma volcanics is therefore a prerequisite to secure knowledge of the prerotation orientation and position of the eastern Santa Monica-Hollywood Fault Zone and of the adjacent field of submarine lava flows.

Intriguing possibilities exist that the source of extrusives in the eastern Santa Monica Mountains is related in some way to the "dioritic plutons" hypothesized as deep sources (Bjorklund and others, 2002) for the sill-like diabase intrusions of the Whittier Fault hanging wall (Yerkes, 1972; McCulloh and others, 2000, p. 1167, fig. 11) and for the El Modeno Volcanics (Yerkes, 1957). Differences in ages and compositions, as well as disparate locations, pose substantial questions and complications to exploration of such possible connections. We therefore wait with interest for explication and full documentation of the bases for these hypothesized plutons.

\section{Stratigraphic and Age Relationships}

The strata containing littoral molluscan fossils that underlie the 17.4-Ma volcanics of the Topanga Formation (Hoots, 1931) have been regarded as part of the Topanga Formation by previous workers. Our data show that these strata are uppermost lower Miocene, supporting their assignment as “Topanga." We agree with Fritsche (1993, fig. 2), who regards the various environmentally diverse lithologic (and cartographic) units previously erected and used to describe the enormous volume of Oligocene-Miocene strata of the western Santa Monica Mountains as complex lithofacies equivalents of one another. Thus, the 17.4-Ma volcanics of the Topanga Formation (Hoots, 1931) might be viewed simply as an older (probably the oldest) unit of the Conejo Volcanics. The ages and stratal relationships, rather than the name, are important.

\section{Ar and Sr Isotopic Dating}

The two geochronological approaches used for dating the volcanic sequence in the eastern Santa Monica Mountains are mutually supportive. Because the ${ }^{40} \mathrm{Ar} /{ }^{39} \mathrm{Ar}$ and $\mathrm{Sr}$ isotopic dating approaches are independent, relying on different materials and systematics, the close agreement of the two data sets greatly strengthens the view that both sets are correct. Our experience with the ${ }^{87} \mathrm{Sr} /{ }^{86} \mathrm{Sr}$ method for such precise dating of young fossils underscores the need to use multiple sample sites, redundant analyses of different sample fractions, care in selection of material for analysis, and quantitative analyses of $\mathrm{Mn}, \mathrm{Fe}$, and $\mathrm{Sr}$ to detect diagenetic alteration. Similarly, age determinations of such fine-grained, submarine basalts by whole-rock incremental ${ }^{40} \mathrm{Ar} /{ }^{39} \mathrm{Ar}$ heating may yield useful age information, provided attention is paid to identification of effects of excess Ar and ${ }^{39} \mathrm{Ar}$ recoil. The results of this study emphasize the need for careful sample selection, multiple sample sites, and the use of complementary dating techniques.

\section{Extent of 17.4-Ma Volcanics of Topanga Formation (Hoots, 1931)}

Surface geologic mapping (for example, Dibblee, 1991) of the volcanics of the easternmost Santa Monica Mountains shows that both individual volcanic units and the entire volcanic sequence thin and pinch out to the northeast (fig. 2). Drill holes south of the Santa Monica-Hollywood-Raymond Fault Zone encountered no volcanic rocks in the basinal region north of the Las Cienegas Fault and west of about longitude $118^{\circ}$ W., with one exception (Yeats, 1973, p.135; Wright, 1991, fig. 18). Palinspastic restoration of 13-14 km of left strike slip on the Hollywood-Raymond Fault Zone (McCulloh and others, 2001) places the outcrops shown on figure 2 adjacent to a region south of the fault zone where strata younger than 16 Ma rest depositionally on a varied basement terrane without intervening older strata (or volcanic rocks)(Yerkes and others, 1965, fig. 5; Lamar, 1970; Davis and others, 1989, fig. 9 and plate 1; Wright, 1991, figs. 4,8; McCulloh and others, 2001, fig. 10).

Whether the Topanga-age volcanics ever extended southward across the Hollywood Fault Zone is not known. Post-volcanic uplift and erosion, followed by subsidence and renewed deposition, is a possibility. Accumulation of the volcanic sequence only on the fault block north (originally northwest) of an ancestral Santa Monica-Hollywood-Raymond Fault Zone is conjectural but also possible (Davis and others, 1989). Possibilities for gaining a conclusive answer are limited by complex structure and structural relief, substantial depths in some places to the critical horizon, a paucity of drill holes deep enough stratigraphically to provide definite control, and limited means to obtain indirect evidence. The presence of subrounded clasts of Santa Monica Slate basement rock types in strata dated faunally as about 15.6 Ma and older in deep cored wells on both sides of the Newport-Inglewood Fault Zone at Inglewood oil field indicates that such basement rocks were exposed to erosion not long after volcanism of earliest Topanga age. The lack of associated volcanic detritus implies erosion from a region devoid of Topanga age volcanic 
rocks at that time. This suggests to us that the region of Santa Monica Slate basement directly southeast of the HollywoodRaymond Fault Zone may never have been covered by volcanic rocks, a view evidently held also by Davis and others (1989), although they did not discuss it or cite evidence.

\section{Age Trends of Volcanism in Southern California}

The new age determinations from the eastern Santa Monica Mountains reported here can be used to critically examine two extant hypotheses that propose systematic trends in the ages of Miocene volcanic rocks in coastal southern California. (1) The first hypothesis (Luyendyk and others, 1998, fig. 3) noted, on the basis of about 20 age determinations, an apparent eastward decrease in the age of volcanism in the western Transverse Ranges and Channel Islands from about 18-17 Ma in the west (originally south, prior to transrotation) to about $16 \mathrm{Ma}$ or even younger in the east (originally north). This age progression, according to Luyendyk and others (1998), may have resulted from the development of a northward-propagating rift between the Channel Islands and the rest of onshore coastal southern California. That hypothesis appears to predict that volcanic rocks in the eastern Santa Monica Mountains should be younger than 16 Ma (Luyendyk and others, 1998, fig. 3), considerably younger than our determination of 17.4 Ma for the age of the Topanga Formation (Hoots, 1931) volcanics in this area. (2) The second hypothesis (Wilson and others, in press, fig. 7) suggests, on the basis of a compilation of more than 30 age determinations, that volcanism in coastal southern California migrated from west to east (in early Miocene, pre-transrotation coordinates) in response to rapid eastward propagation of a slab window that, in turn, resulted from breakup and partial subduction of the Monterey plate. This hypothesis leads to the prediction that volcanism in the eastern Santa Monica Mountains should be between 17.5 and 16.0 Ma but closer to the latter age (Wilson and others, in press, fig. 7).

The apparent discrepancies between the predictions of these two hypotheses and the newly determined 17.4-Ma age of the Topanga Formation (Hoots, 1931) volcanics in the eastern Santa Monica Mountains show that our understanding of the tectonic controls on the ages and locations of volcanic centers in coastal southern California remains imperfect. This lack of agreement underscores the need for further work.

\section{Acknowledgments}

The work reported here was made possible through the cooperation of the University of Texas at Dallas. R. J. Enrico provided important paleontological assistance. Early inspiration came during 1999 fieldwork with I. P. Colburn. J. W. Hillhouse and D. M. Morton encouraged the work in several ways. We are grateful to Linda Barth, Rob Hancock, Steve Lipshie, Mark Oborne, Cliff Plumb, Jim Shuttleworth, and Mark Stipanovich of the City of Los Angeles Departments of
Recreation and Parks, Public Works, and Water and Power for permissions to collect samples along roadways and on city lands. N. R. Miller provided the ICP trace-element analysis of fossil carbonates. We are grateful to C. L. Powell and Zenon Valin for figure preparation. Critical reviews by R. H. Campbell and R. W. Kistler are appreciated.

\section{References}

Arnold, Ralph, 1907, New and characteristic species of fossil mollusks from the oil-bearing Tertiary formations of southern California: U. S. National Museum Proceedings, v. 32, p. 525-546.

Atwater, Tanya, 1989, Plate tectonic history of the northeast Pacific and western North America, in Winterer, E.L., Hussong, D.M., and Decker, R.W., eds., The eastern Pacific Ocean and Hawaii: Geological Society of America, The Geology of North America, v. N, p. 21-72.

Atwater, Tanya, and Stock, Joann, 1998, Pacific-North America plate tectonics of the Neogene southwestern United States; an update: International Geology Review, v. 40, p. 375402.

Barron, J.A., and Isaacs, C.M., 2001, Updated chronostratigraphic framework for the California Miocene, in Isaacs, C.M., and Rullkötter, Jürgen, eds., The Monterey Formation from Rocks to Molecules: New York, Columbia University Press, p. 393-395.

Bartow, J.A., 1992, Neogene timescale for southern California: U. S. Geological Survey Open-File Report 92-212, 2 sheets.

Berry, A.L., Dalrymple, G.B., Lanphere, M.A., and Von Essen, J.C., compilers and eds., 1976, Summary of miscellaneous potassium-argon age measurements, U. S. Geological Survey, Menlo Park, California, for the years 1972-74: U. S. Geological Survey Circular 727, 13 p.

Bjorklund, Tom, Burke, Kevin, Zhou, Hua-Wei, and Yeats, R. S., 2002, Miocene rifting in the Los Angeles basin; evidence from the Puente Hills half-graben, volcanic rocks, and Pwave tomography: Geology, v. 30, p. 451-454.

Blake, G. H., Jr., 1991, Review of the Neogene biostratigraphy of the Los Angeles basin and implications for basin evolution, in Biddle, K. T., ed., Active basin margins: American Association of Petroleum Geologists Memoir 52, p. 135-184.

Bohannon, R. G., and Geist, Eric, 1998, Upper crustal structure and Neogene tectonic development of the California continental borderland: Geological Society of America Bulletin, v. 110, p. 779-800.

Brand, Uwe, and Veizer, Jan, 1980, Chemical diagenesis of a multicomponent carbonate system -1 . Trace elements: Journal of Sedimentary Petrology, v. 50, p. 1219-1236.

Burgess, R., Kelley, S.P., Parsons, I., Walker, F.D.L., and Worden, R.H., $1992,{ }^{40} \mathrm{Ar} /{ }^{39} \mathrm{Ar}$ analysis of perthite microstructures and fluid inclusions in alkali feldspars from the Klokken syenite, South Greenland: Earth and Planetary Science Letters, v. 109, p. 147-167. 
Burke, W. H., and Hetherington, E. A., 1984, Normalizing ${ }^{87} \mathrm{Sr} /$ ${ }^{86} \mathrm{Sr}$ by multiple collection and comparison to a standard: Chemical Geology, v. 12, p. 265-268.

Castle, R. O., and Yerkes, R. F., 1976, Recent surface movements in the Baldwin Hills, Los Angeles County, California: U. S. Geological Survey Professional Paper 882, 125 p.

Claesson, S., and Roddick, J. C., $1983,{ }^{40} \mathrm{Ar} /{ }^{39} \mathrm{Ar}$ data on the age and metamorphism of the Ottfjallet dolerites, Sarv Nappe, Swedish Caledonides: Lithos, v. 16, p. 61-73.

Colburn, I. P., and Novak, G. A., 1989, Paleocene conglomerates of the Santa Monica Mountains, California; petrology, stratigraphy, and environments of deposition, in Colburn, I. P., Abbott, P. L., and Minch, J., eds., Conglomerates in basin analysis; a symposium dedicated to A. O. Woodford: Society of Economic Paleontologists and Mineralogists, Pacific Section, Book 62, p. 227-253.

Conrad, C. L., and Ehlig, P. L., 1983, The Monterey Formation of the Palos Verdes Peninsula, California - an example of sedimentation in a tectonically active basin within the California Continental Borderland, in Larue, D. K., and Steel, R. J., eds., Cenozoic marine sedimentation, Pacific Margin, U. S. A.: Los Angeles, Society of Economic Paleontologists and Mineralogists, Pacific Section, p. 103-116.

Crouch, J. K., 1981, Northwest margin of California Continental Borderland; marine geology and tectonic evolution: American Association of Petroleum Geologists Bulletin, v. 65 , p. 191-218.

Crouch, J. K., and Suppe, John, 1993, Late Cenozoic tectonic evolution of the Los Angeles basin and inner California borderland; a model for core-complex-like crustal extension: Geological Society of America Bulletin, v. 105, p. 1415-1434.

Crowe, B. M., McLean, Hugh, Howell, D. G., and Higgins, R. E., 1976, Petrography and major-element chemistry of the Santa Cruz Island Volcanics, in Howell, D. G., ed., Aspects of the geologic history of the California Continental Borderland: American Association of Petroleum Geologists, Pacific Section, Miscellaneous Publication 24, p. 196-215.

Dalrymple, G.B., 1989, The GLM continuous laser system for ${ }^{40} \mathrm{Ar} /{ }^{39} \mathrm{Ar}$ dating; description and performance characteristics: U. S. Geological Survey Bulletin 1890, p.89-96.

Dalrymple, G. B., and Duffield, W. A., 1988, High precision ${ }^{40} \mathrm{Ar} /{ }^{39} \mathrm{Ar}$ dating of Oligocene rhyolites from the Mogollon-Datil volcanic field using a continuous laser system: Geophysical Research Letters, v. 15, p. 463-466.

Davis, T. L., Namson, Jay, and Yerkes, R. F., 1989, A cross section of the Los Angeles area; seismically active fold and thrust belt, the 1987 Whittier Narrows earthquake, and earthquake hazard: Journal of Geophysical Research, v. 94, n. B7, p. 9644-9664.

Denison, R. E., Koepnick, R. B., Fletcher, A., Howell, M. W., and Calloway, W. S., 1994, Criteria for the retention of original seawater ${ }^{87} \mathrm{Sr} /{ }^{86} \mathrm{Sr}$ in ancient shelf limestones: Chemical Geology, v. 112, p. 131-143.

Dibblee, T. W., Jr., 1982, Geology of the Santa Monica Moun- tains and Simi Hills, southern California, in Fife, D. L., and Minch, J. A., eds., Geology and mineral wealth of the California Transverse Ranges: Santa Ana, California, South Coast Geological Society, Inc., p. 94-130.

Dibblee, T. W., Jr., 1989, Mid-Tertiary conglomerates and sandstones on the margin of the Ventura and Los Angeles basins and their tectonic significance, in Colburn, I. P., Abbott, P. L., and Minch, J., eds., Conglomerates in basin analysis; a symposium dedicated to A. O. Woodford: Society of Economic Paleontologists and Mineralogists, Pacific Section, Book 62, p. 207-226.

Dibblee, T. W., Jr., 1991, Geologic map of the Hollywood and Burbank (south 1/2) Quadrangles, Los Angeles County, California: Dibblee Geological Foundation Map DF-30, 1:24,000.

Dickinson, W. R., 1996, Kinematics of transrotational tectonism in the California Transverse Ranges and its contribution to cumulative slip along the San Andreas transform fault system: Geological Society of America Special Paper 305, $46 \mathrm{p}$.

Dickinson, W. R., 1997, Tectonic implications of Cenozoic volcanism in coastal California: Geological Society of America Bulletin, v. 109, p. 936-954.

Duffield, W. A., and Dalyrmple, G. B., 1990, The Taylor Creek Rhyolite of New Mexico; a rapidly emplaced field of lava domes and flows: Bulletin of Volcanology, v. 52, p. 475-487.

Durrell, Cordell, 1954, Geology of the Santa Monica Mountains, Los Angeles and Ventura Counties [California], in Jahns, R. H., ed., Geology of Southern California: California Division of Mines Bulletin 170, map sheet 8, scale 1: 126,720 .

Eaton, G. P., 1958, Miocene volcanic activity in the Los Angeles Basin, in Higgins, J. W., ed., A guide to the geology and oil fields of the Los Angeles and Ventura regions: American Association of Petroleum Geologists, Pacific Section, p. 55-61.

Fleck, R.J., Sutter, J.F., and Elliot, D.H., 1977, Interpretation of discordant ${ }^{40} \mathrm{Ar} /{ }^{39} \mathrm{Ar}$ age spectra of Mesozoic tholeiites from Antarctica: Geochimica et Cosmochimica Acta, v.41, p.15-32.

Forman, J. A., 1970, Age of the Catalina Island pluton, California: Geological Society of America Special Paper 124, p. 37-45.

Fritsche, A. E., 1993, Middle Tertiary stratigraphic terminology for the Santa Monica Mountains, southern California, in Weigand, P. W., Fritsche, A. E., and Davis, G. E., eds., Depositional and volcanic environments of middle Tertiary rocks in the Santa Monica Mountains, southern California: Society for Sedimentary Geology, Pacific Section, Book 72, p. 1-12.

Graves, D. T., 1954, Geology of the Dominguez oil field, in Jahns, R. H., ed., Geology of southern California: California Division of Mines Bulletin 170, map sheet 32, scale 1:12,000.

Harris, P. B., 1958, Long Beach Airport pool, in Higgins, J. W., ed., A guide to the geology and oil fields of the Los 
Angeles and Ventura regions: American Association of Petroleum Geologists, Pacific Section, p. 75-77.

Harrison, T. M., and McDougall, Ian, 1981, Excess ${ }^{40} \mathrm{Ar}$ in metamorphic rocks from Broken Hill, New South Wales; implications for ${ }^{40} \mathrm{Ar} /{ }^{39} \mathrm{Ar}$ age spectra and the thermal history of the region: Earth and Planetary Science Letters, v. 55 , p. $123-149$.

Harrison, T. M., Heizler, M. T., and Lovera, O. M., 1993, In vacuo crushing experiments and K-feldspar thermochronometry: Earth and Planetary Sciences Letters, v. 117, p. $169-180$.

Harrison, T. M., Heizler, M. T., Lovera, O. M., Chen, Wenji, and Grove, Marty, 1994, A chlorine disinfectant for excess argon released from K-feldspar during step heating: Earth and Planetary Science Letters, v. 123, p. 95-104.

Hawkins, J. W., Jr., Allison, E. C., and MacDougall, Doug, 1971, Volcanic petrology and geologic history of Northeast Bank, southern California borderland: Geological Society of America Bulletin, v. 82, p. 219-228.

Higgins, R. E., 1976, Major-element chemistry of the Cenozoic volcanic rocks in the Los Angeles Basin and vicinity, in Howell, D. G., ed., Aspects of the geologic history of the California Continental Borderland: American Association of Petroleum Geologists, Pacific Section, Miscellaneous Publication 24, p. 216-227.

Hoots, H. W., 1931, Geology of the eastern part of the Santa Monica Mountains, Los Angeles County, California: U. S. Geological Survey Professional Paper 165-C, p. 83- 134, map scale 1:24,000.

Hornafius, J. S., Luyendyk, B. P., Terres, R. R., and Kamerling, M J., 1986, Timing and extent of Neogene tectonic rotation in the western Transverse Ranges, California: Geological Society of America Bulletin, v. 97, p. 1476-1487.

Huneke, J. C., and Smith, S. P., 1976, The realities of recoil: ${ }^{39} \mathrm{Ar}$ recoil out of small grains and anomalous age patterns in ${ }^{39} \mathrm{Ar} /{ }^{40} \mathrm{Ar}$ dating: Geochimica et Cosmochimica Acta Supplement 7 (Proceedings of the Seventh Lunar Science Conference), p. 1987-2008.

Johnson, C. M., and O’Neil, J. R., 1984, Triple junction magmatism; a geochemical study of Neogene volcanic rocks in western California: Earth and Planetary Science Letters, v. 71, p. 241-262.

Jones, C. E., Jenkyns, H. C., and Hesselbo, S. P., 1994, Strontium isotopes in Early Jurassic seawater: Geochimica et Cosmochimica Acta, v. 58, p. 1285-1301.

Kamerling, M. J., and Luyendyk, B.P., 1979, Tectonic rotations of the Santa Monica Mountains region, western Transverse Ranges, California, suggested by paleomagnetic vectors: Geological Society of America Bulletin, v. 90, p. 331-337.

Kew, W. S. W., 1923, Geologic formations of a part of southern California and their correlation: American Association of Petroleum Geologists Bulletin, v. 7, p. 411-420.

Lamar, D. L., 1970, Geology of the Elysian Park-Repetto Hills area, Los Angeles County, California: California Division of Mines and Geology Special Report 101, 45 p., map scale 1:24,000.
Lanphere, M.A., and Dalrymple, G.B., 1976, Identification of excess ${ }^{40} \mathrm{Ar}$ by the ${ }^{40} \mathrm{Ar} /{ }^{39} \mathrm{Ar}$ age spectrum technique: Earth and Planetary Science Letters, v. 32, p. 141-148.

Legg, M. R., 1991, Developments in understanding the tectonic evolution of the California Continental Borderland: Society of Exploration Paleontologists and Mineralogists Special Publication No. 46, p. 291-312.

Ludwig, K.R., 2001, Users Manual for Isoplot/Ex (rev. 2.49); a geological toolkit for

Microsoft Excel: Berkeley Geochronology Center Special Publication 1a, $56 \mathrm{p}$.

Luyendyk, B. P., 1990, Neogene-age fault slip in the continental transform zone in Southern California: Annales Tectonicae, Special issue, v. IV, no. 2, p. 24-34.

Luyendyk, B. P., Gans, P. B., and Kamerling, M. J., 1998, Geochronology of southern California Neogene volcanism, in Weigand, P. W., ed., Contributions to the geology of the Northern Channel Islands, southern California: American Association of Petroleum Geologists, Pacific Section, Miscellaneous Publication 45, p. 9-35.

McArthur, J. M., Crame, J. A., and Thirlwall, M. F., 2000, Definition of Late Cretaceous stage boundaries in Antarctica using strontium isotope stratigraphy: Journal of Geology, v. 108 , p. 623-640.

McArthur, J. M., Howarth, R. J., and Bailey, T. R., 2001, Strontium isotope stratigraphy; LOWESS Version 3; best fit to the marine Sr-isotope curve for 0-509 Ma and accompanying look-up table for deriving numerical age: Journal of Geology, v. 109, p. 155-170.

McCulloh, T. H., Beyer, L. A., and Enrico, R. J., 2000, Paleocene strata of the eastern Los Angeles basin, California; paleogeography and constraints on Neogene structural evolution: Geological Society of America Bulletin, v. 112 , p. 1155-1178.

McCulloh, T. H., Beyer, L. A., and Morin, R. W., 2001, Mountain Meadows Dacite; Oligocene intrusive complex that welds together the Los Angeles Basin, northwestern Peninsular Ranges, and central Transverse Ranges, California: U. S. Geological Survey Professional Paper 1649, 34 p.

McIntyre, G. A., Brooks, C., Compston, W., and Turek, A., 1966, The statistical assessment of Rb-Sr isochrons: Journal of Geophysical Research, v. 71, p. 5459-5468.

Mefford, M. G., 1970, Murphy area of Las Cienegas oil field: California Division of Oil and Gas, California Oil Fields, v. 56, n. 1, p. $5-13$.

Merrihue, Craig, and Turner, Grenville, 1966, Potassium-argon dating by activation with fast neutrons: Journal of Geophysical Research, v. 71, p. 2852-2857.

Miller, F. K., and Morton, D. M., 1980, Potassium-argon geochronology of the eastern Transverse Ranges and southern Mojave Desert, southern California: U. S. Geological Survey Professional Paper 1152, 30 p.

Neuerburg, G. J., 1953, Geology of the Griffith Park area, Los Angeles County, California: California Division of Mines Special Report 33, 29 p.

Nicholson, Craig, Sorlien, C. C., Atwater, Tanya, Crowell, J. C., and Luyendyk, B. P., 1994, Microplate capture, rotation of 
the western Transverse Ranges, and initiation of the San Andreas transform as a low-angle fault system: Geology, v. 22, p. 491-495.

Nourse, J. A., Weigand, P. W., and Hazelton, G. B., 1998, Igneous and tectonic response of the eastern San Gabriel Mountains to Neogene extension and rotation of the Transverse Ranges block, in Behl, R. J., ed., Guidebook of field trip \#10, 94th Annual Meeting, Cordilleran Section: Long Beach, California, Geological Society of America, p. $10-1$ to $10-15$.

Redin, T. W., 1991, Oil and gas production from submarine fans of the Los Angeles basin, in Biddle, K. T., ed., Active basin margins: American Association of Petroleum Geologists Memoir 52, p. 239-259.

Samson, S. D., and Alexander, E. C., 1987, Calibration of the interlaboratory ${ }^{40} \mathrm{Ar} /{ }^{39} \mathrm{Ar}$ dating standard, MMhb-1: Chemical Geology (Isotope Geoscience Section), v. 66, p. 27-34.

Schneider, C. L., Hummon, C., Yeats, R. S., and Huftile, G. L., 1996, Structural evolution of the northern Los Angeles basin, California, based on growth strata: Tectonics, v. 15,p. 341-355.

Severinghaus, Jeff, and Atwater, Tanya, 1990, Cenozoic geometry and thermal state of the subducting slabs beneath western North America, in Wernicke, B. P., ed., Basin and Range extensional tectonics near the latitude of Las Vegas, Nevada: Geological Society of America Memoir 176, p. 1-22.

Shelton, J.S., 1946, Geology of northeast margin of San Gabriel Basin, Los Angeles County, California: U. S. Geological Survey Oil and Gas Investigation Preliminary Map 63, scale 1:24,000.

Shelton, J. S., 1955, Glendora Volcanic rocks, Los Angeles basin, California: Geological Society of America Bulletin, v. 66, p. 45-90.

Steiger, R. H., and Jager, E., 1977, Subcommission on geochronology; convention on the use of decay constants in geo- and cosmochronology: Earth and Planetary Science Letters, v. 36, p. 359-362.

Sullwold, H. H., Jr., 1960, Tarzana fan, deep submarine fan of late Miocene age, Los Angeles County, California: American Association of Petroleum Geologists Bulletin, v. 44, p. 433-457.

Tedford, R. H., Skinner, M. F., Fields, R. W., Remsberger, J. M., Whistler, D. P., Galusha, Theodore, Taylor, B. E., Macdonald, J. R., and Webb, S. D., 1987, Faunal succession and biochronology of the Arikareean through Hemphillian interval (late Oligocene through earliest Pliocene epochs) in North America, in Woodburne, M. O., ed., Cenozoic Mammals of North American: Berkeley, University of California Press, p. 153-210.

Tsutsumi, Hiroyuki, Yeats, R. S., and Huftile, G. J., 2001, Late Cenozoic tectonics of the northern Los Angeles fault system, California: Geological Society of America Bulletin, v. 113, p. 454-468.

Turner, D. L., 1970, Potassium-argon dating of Pacific Coast foraminiferal stages, in Bandy, O. L., ed., Radiometric dating and paleontologic zonation: Geological Society of America Special Paper 124, p. 91-129.

Turner, D. L., and Campbell, R. H., 1979, Age of the Conejo Volcanics, in Yerkes, R. F., and Campbell, R. H., eds., Stratigraphic nomenclature of the Central Santa Monica Mountains, Los Angeles County, California: U. S. Geological Survey Bulletin 1457-E, p. E18-E22.

Turner, G., and Bannon, M.P., 1992, Argon isotope geochemistry of inclusion fluids from granite-associated mineral veins in southwest and northeast England: Geochimica et Cosmochimica Acta, v. 56, p. 227-243.

Turner, G., and Cadogan, P.H., 1974, Possible effects of ${ }^{39} \mathrm{Ar}$ recoil in ${ }^{40} \mathrm{Ar} /{ }^{39} \mathrm{Ar}$ dating: Geochimica et Cosmochimica Acta Supplement 5 (Proceedings of the Fifth Lunar Science Conference), p.1601-1615.

Turner, G., and Wang, S., 1992, Excess argon, crustal fluids, and apparent isochrons from crushing K-feldspar: Earth and Planetary Science Letters, v. 110, p. 193-211.

Vedder, J. G., 1973, Geologic framework and correlation of Miocene rocks in the Caliente Range: American Association of Petroleum Geologists-Society of Economic Paleontologists and Mineralogists-Society of Exploration Geophysicists, Pacific Section, Annual Meeting Field Trip 2, p. 42-60.

Vedder, J. G., 1987, Regional geology and petroleum potential of the Southern California Borderland, in Scholl, D. W., Grantz, Arthur, and Vedder, J. G., eds., Geology and resource potential of the continental margin of western North America and adjacent ocean basins - Beaufort Sea to Baja California: Houston, Texas, Circum-Pacific Council for Energy and Mineral Resources, Earth Science Series, v. 6, p. 403-447.

Vedder, J. G., Yerkes, R. F., and Schoellhamer, J. E., 1957, Geologic map of the San Joaquin Hills-San Juan Capistrano area, Orange County, California: U. S. Geological Survey Oil and Gas Investigations Map OM-193, scale $1: 24,000$.

Vedder, J. G., Howell, D. G., and Forman, J. A., 1979, Miocene strata and their relation to other rocks, Santa Catalina Island, California, in Armentrout, J. M., Cole, M. R., and TerBest, H., Jr., eds., Cenozoic paleogeography of the western United States: Los Angeles, Society of Economic Paleontologists and Mineralogists, Pacific Section, p. 239-256.

Veizer, Ján, Buhl, Dieter, Diener, Andreas, Ebneth, Stefan, Podlaha, O. G., Bruckschen, Peter, Jasper, Torsten, Korte, Christoph, Schaaf, Michael, Ala, Davin, and Azmy, Karem, 1997, Strontium isotope stratigraphy; potential resolution and event correlation: Palaeogeography, Palaeoclimatology, Palaeoecology, v. 132, p. 65-77.

Weigand, P. W., 1982, Middle Cenozoic volcanism of the western Transverse Ranges, in Fife, D. L., and Minch, J. A., eds., Geology and mineral wealth of the California Transverse Ranges: Santa Ana, California, South Coast Geological Society, Inc., p. 170-188.

Weigand, P. W., and Savage, K. L., 1993, Review of the petrology and geochemistry of the Miocene Conejo Volcanics 
of the Santa Monica Mountains, California, in Weigand, P. W., Fritsche, A. E., and Davis, G. E., eds., Depositional and volcanic environments of middle Tertiary rocks in the Santa Monica Mountains, southern California: Society for Sedimentary Geology, Pacific Section, Book 72, p. 93-112.

Weigand, P. W., Savage, K. L., Reid, T., and Chinn, B. D., 1998, Composition of volcanic rocks on Santa Rosa, San Miguel, and Santa Barbara Islands, California, in Weigand, P. W., ed., Contributions to the geology of the Northern Channel Islands, Southern California: Bakersfield, California, American Association of Petroleum Geologists, Pacific Section, Miscellaneous Publication 45, p. 37-47.

West, J. C., and Redin, T. W., 1990, Correlation section across northern Los Angeles basin from Santa Monica Bay to Prado flood control basin: Los Angeles, American Association of Petroleum Geologists, Pacific Section, Correlation Section Series, CS 28, scale 1:48,000 (horizontal), $1: 12,000$ (vertical).

West, J. C., and Redin, T. W., 1991, Correlation section across eastern Los Angeles basin from San Pedro Bay to San Gabriel Mts., Correlation Section Series: Los Angeles, American Association of Petroleum Geologists, Pacific Section, Correlation Section Series, CS 29, scale 1:48,000 (horizontal), 1:12,000 (vertical).

White, R. T., 1952, Cenozoic correlation section across Los Angeles Basin from Palos Verdes Hills to San Gabriel Mts., California: American Association of Petroleum Geologists, Pacific Section, scale 1:24,000.

Wilson, D.S., McCrory, P.A., and Stanley, R.G., in press, Implications of volcanism in coastal California for the deformation history of western North America: Tectonics.

Woodring, W. P., Bramlette, M. N., and Kew, W. S., 1946, Geology and paleontology of Palos Verdes Hills, California: U. S. Geological Survey Professional Paper 207, 145 p.

Wright, T. L., 1991, Structural geology and tectonic evolution of the Los Angeles basin, California, in Biddle, K. T., ed., Active Basin Margins: American Association of Petroleum Geologists Memoir 52, p. 35-134.

Yeats, R. S., 1973, Newport-Inglewood fault zone, Los Angeles basin, California: American Association of Petroleum Geologists Bulletin, v. 57, p. 117-135.

Yerkes, R. F., 1957, Volcanic rocks of the El Modeno area, Orange County, California: U. S. Geological Survey Professional Paper 274-L, p. 313-334.

Yerkes, R. F., 1972, Geology and oil resources of the western Puente Hills area, Southern California: U. S. Geological Survey Professional Paper 420-C, 63 p.

Yerkes, R. F., and Campbell, R. H., 1979, Stratigraphic nomenclature of the central Santa Monica Mountains, Los Angeles County, California: U. S. Geological Survey Bulletin 1457-E, p. E1-E31.

Yerkes, R. F., McCulloh, T. H., Schoellhamer, J. E., and Vedder, J. G., 1965, Geology of the Los Angeles basin, California-an introduction: U. S. Geological Survey Professional Paper 420-A, 57 p.

York, Derek, Hall, C. M., Yanase, Yotaro, Hanes, J. A., and
Kenyon, M. J., $1981,{ }^{40} \mathrm{Ar} /{ }^{39}$ Ar dating of terrestrial minerals with a continuous laser: Geophysical Research Letters, v. 8 , p. 1136-1138.

Zeitler, P. K., and FitzGerald, J. D., 1986, Saddle-shaped ${ }^{40} \mathrm{Ar} /$

${ }^{39} \mathrm{Ar}$ age spectra from young, microstructurally complex potassium feldspars: Geochimica et Cosmochimica Acta, v. 50 , p. $1185-1199$.

\section{Appendix}

\section{Techniques and Interpretations of ${ }^{40} \mathrm{Ar} /{ }^{39} \mathrm{Ar}$ and ${ }^{87} \mathrm{Sr} /{ }^{86} \mathrm{Sr}$ Dating}

\section{${ }^{40} \mathrm{Ar} /{ }^{39} \mathrm{Ar}$ Analytical Techniques}

In the ${ }^{40} \mathrm{Ar} /{ }^{39} \mathrm{Ar}$ or $\mathrm{Ar}-\mathrm{Ar}$ dating technique (Merrihue and Turner, 1966), samples are irradiated with fast neutrons, converting ${ }^{39} \mathrm{~K}$ to ${ }^{39} \mathrm{Ar}$ in potassium-bearing materials. The

${ }^{39} \mathrm{Ar}$, representing the radioactive parent, and ${ }^{40} \mathrm{Ar}$, the decay product, are measured simultaneously by mass spectrometry, increasing the precision and utility of conventional $\mathrm{K}$-Ar dating. In the present study, Ar was released from volcanic samples of the Topanga Formation (Hoots, 1931) and Glendora Volcanics by the incremental-heating (or "age spectrum") method. In this method, step-wise heating of the material evolves the neutron-produced ${ }^{39} \mathrm{Ar}$ together with the radiogenic ${ }^{40} \mathrm{Ar}$, atmospheric ${ }^{40} \mathrm{Ar}$, and any extraneous ${ }^{40} \mathrm{Ar}$ in sequential steps or increments. The ${ }^{40} \mathrm{Ar} /{ }^{39} \mathrm{Ar}$ age spectrum is a graphical display of apparent age versus cumulative percent ${ }^{39} \mathrm{Ar}$ released. The ${ }^{40} \mathrm{Ar} /{ }^{39} \mathrm{Ar}$ laser-fusion technique, fusing extremely small amounts of material with a continuous laser (York and others, 1981), was used in this study to analyze standard minerals (Taylor Creek Rhyolite sanidine; see Dalrymple and Duffield, 1988) that determine the neutron-flux.

Ar analyses were performed on the same mass spectrometer using the same argon-extraction system described by Dalrymple (1989). Incremental-heating analyses used a low-blank, tantalum and molybdenum, resistance-heated furnace, commonly releasing all of the Ar in 8 to 15 heating increments. Samples used in this study were irradiated for 16-20 hours in the U.S. Geological Survey TRIGA Reactor Facility in Denver, Colorado. The neutron flux monitor used in all irradiations was Taylor Creek Rhyolite sanidine, 85G003, with an age of $27.92 \mathrm{Ma}$, as reported by Duffield and Dalrymple (1990). This age is standardized to an average age of 513.9 Ma for interlaboratory standard hornblende, MMhb1 (Samson and Alexander, 1987) and the Menlo Park intralaboratory standard biotite, SB-3. Decay and abundance constants for all ages reported are those recommended by Steiger and Jager (1977). Analytical errors in ${ }^{40} \mathrm{Ar} /{ }^{39} \mathrm{Ar}$ ages are reported at the $1 \sigma$ level. Plateau ages of ${ }^{40} \mathrm{Ar} /{ }^{39} \mathrm{Ar}$ age spectra are defined as the weighted mean ages of contiguous gas fractions representing more than 50 percent of the ${ }^{39} \mathrm{Ar}$ released for which no difference can be detected between the 
ages of any two fractions at the 95-percent level of confidence (Fleck and others, 1977). Analytical results are summarized in table 3 and illustrated graphically in figures 5-7.

\section{Interpretation of ${ }^{40} \mathrm{Ar} /{ }^{39} \mathrm{Ar}$ Incremental-Heating Experiments}

\section{${ }^{40} \mathrm{Ar} /{ }^{39} \mathrm{Ar}$ results from the eastern Santa Monica Mountains}

The ${ }^{40} \mathrm{Ar} /{ }^{39} \mathrm{Ar}$ age spectra of the basalts from the eastern Santa Monica Mountains (fig. 5) define "U-shaped" or "saddle-shaped" patterns typical of excess radiogenic ${ }^{40} \mathrm{Ar}$ (Lanphere and Dalrymple, 1976; Harrison and McDougall, 1981). In U-shaped spectra, apparent ages decrease from values greater than the true age of the sample to values that approach that age and then increase again to values often far above this minimum. Harrison and McDougall (1981) attributed U-shaped spectra to incorporation of argon into anion vacancies in mineral phases at temperatures at or below about $350^{\circ} \mathrm{C}$. Claesson and Roddick (1983) documented a strong correlation between the release of excess ${ }^{40} \mathrm{Ar}$ and release of Ar isotopes derived from irradiating chlorine. They argued that excess ${ }^{40} \mathrm{Ar}$ is related solely to anion lattice sites. Studies in which chlorine and excess ${ }^{40} \mathrm{Ar}$ were released by crushing in vacuum support the interpretation that fluid-inclusion and grain-boundary sites are sources for these species released at low temperatures, whereas excesses released at high temperatures are consistent with the higher activation energies required to liberate chlorine and other anions from mineral lattice sites (Turner and Wang, 1992; Burgess and others, 1992; Harrison and others, 1993). At intermediate temperatures, an absence or reduced release of excess ${ }^{40} \mathrm{Ar}$ coincides with the primary release of radiogenic ${ }^{40} \mathrm{Ar}$, producing the minima in these U-shaped age spectra. Although this central portion of the U-shaped spectrum may give reliable estimates of the age of the material, this minimum may only approach the true age of the sample, especially where the total percentage of excess ${ }^{40} \mathrm{Ar}$ is large (Lanphere and Dalrymple, 1976; Harrison and McDougall, 1981; Zeitler and FitzGerald, 1986). A valid estimate of the true age of these samples depends on obtaining increments with a minimum of excess

${ }^{40} \mathrm{Ar}$, which depends in turn on both the total amount of excess ${ }^{40} \mathrm{Ar}$ and the resolution of the analysis (the percentage of gas released in each increment).

In some cases the correlation of chlorine-derived ${ }^{38} \mathrm{Ar}$ with excess ${ }^{40} \mathrm{Ar}$ has been used to identify the excess component and correct ${ }^{40} \mathrm{Ar} /{ }^{39} \mathrm{Ar}$ ages (Turner and Bannon, 1992; Harrison and others, 1993, 1994). The three basalt samples (A through C) from the Topanga Formation (Hoots, 1931) all yield U-shaped age spectra that decrease moderately to an age between 17.2 and 17.4 Ma before increasing irregularly to values above $30 \mathrm{Ma}$ (fig. 5, table 3). As shown in figure 5 by the variation of $\mathrm{Cl} / \mathrm{K}$, this $\mathrm{U}$-shaped pattern is also reflected in the release of chlorine-derived ${ }^{38} \mathrm{Ar}$. Spectra from sample C reveal an especially large high-temperature release of excess
${ }^{40} \mathrm{Ar}$ that is strongly correlated with an increase in $\mathrm{Cl} / \mathrm{K}$. If the true age of this sample is defined by the intermediatetemperature minimum of $17.27 \pm 0.45 \mathrm{Ma}$ in the $875^{\circ} \mathrm{C}$ step, excess ${ }^{40} \mathrm{Ar}$ released in low-temperature increments $\left(625^{\circ} \mathrm{C}\right.$ to $800^{\circ} \mathrm{C}$ steps) for this sample ranges from about 4 percent to about 8 percent in each step. Although 17.27 \pm 0.45 Ma represents a maximum age for this sample, we accept it as the best estimate of the true age. The pattern of $\mathrm{Cl} / \mathrm{K}$ released mimics that for age, with the substantial increase in both parameters occurring after the $875^{\circ} \mathrm{C}$ step.

Like the pattern of Ar release for sample $\mathrm{C}$, the age minimum of the ${ }^{40} \mathrm{Ar} /{ }^{39} \mathrm{Ar}$ spectrum for sample B occurs in a single step, as the ages decrease from more than $20 \mathrm{Ma}$ to $17.38 \pm 0.11 \mathrm{Ma}$ before increasing at higher temperatures (fig. 5, table 3). $\mathrm{Cl} / \mathrm{K}$ follows a similar, U-shaped pattern with substantially higher $\mathrm{Cl} / \mathrm{K}$ at high temperature. Ages derived from increments above $925^{\circ} \mathrm{C}$ in this sample have larger uncertainties and show less systematic variation than in sample C. Comparing the total-gas ages of the two samples, however, the total amount of excess ${ }^{40} \mathrm{Ar}$ in sample B is substantially less than in sample $C$. The best estimate age for sample B is $17.38 \pm 0.11 \mathrm{Ma}$, but this may represent only a maximum age, because ages of adjacent increments are substantially higher.

Incremental heating of sample A provides the most interpretable age spectrum of the three samples from the eastern Santa Monica Mountains. As with the others, ${ }^{40} \mathrm{Ar} /$ ${ }^{39} \mathrm{Ar}$ results define a U-shaped pattern, with ages decreasing from $19 \mathrm{Ma}$ to a two-step minimum of $17.38 \pm 0.12 \mathrm{Ma}$ in the $725^{\circ} \mathrm{C}$ and $800^{\circ} \mathrm{C}$ steps. In this case the age derived from the $875^{\circ} \mathrm{C}$ step, the next higher temperature, is only slightly higher, suggesting little or no excess ${ }^{40} \mathrm{Ar}$ and confirming the close approach to the true age. The ages derived from subsequent temperature steps, however, increase to values well above $30 \mathrm{Ma}$ (fig. 3, table 3 ). $\mathrm{Cl} / \mathrm{K}$ values show a similar pattern, with an abrupt increase coinciding with a correlative increase in apparent age at $1,100^{\circ} \mathrm{C}$. We consider the $17.38 \pm 0.12 \mathrm{Ma}$ average age of the $725^{\circ} \mathrm{C}$ and $800^{\circ} \mathrm{C}$ steps to represent the true age of the basalt. The agreement of these two lowest-age increments that represent more than 30 percent of the ${ }^{39} \mathrm{Ar}$ released, the limited excess ${ }^{40} \mathrm{Ar}$ apparent in adjacent steps, and the near coincidence of the age and $\mathrm{Cl} / \mathrm{K}$ minima strongly support this interpretation.

Within analytical uncertainties, the ages derived from the four steps representing the minima of the three age spectra are the same, yielding a weighted mean age of $17.38 \pm 0.08$ Ma and a mean square of weighted deviates or MSWD (see McIntyre and others, 1966) of 0.04. Because of the clear evidence of excess ${ }^{40} \mathrm{Ar}$ in these basalts, this age must be considered a maximum for the time of lava extrusion. The close agreement of the minimum ages of the three samples, however, suggests that this age may represent that event quite closely. The age is in the early Miocene and approximately equivalent to the latest Saucesian provincial benthic foraminiferal stage, about $1.5 \mathrm{~m}$.y. older than the lowest part of the Conejo Volcanics (Turner and Campbell, 1979; Barron and Isaacs, 2001). 
Table 3.- Incremental heating ${ }^{40} \mathrm{Ar} /{ }^{39} \mathrm{Ar}$ ages of volcanic rocks of the Topanga Formation (Hoots, 1931) from the eastern Santa Monica Mountains and Glendora Volcanics, California.

[See figures 1 and 2 for sample localities. Constants used for Ar computations are $\lambda_{\beta}=4.962 \times 10^{-10} \mathrm{yr}^{-1}, \lambda_{\varepsilon}=0.581 \times 10^{-10} \mathrm{yr}^{-1}$, and ${ }^{40} \mathrm{~K} / \mathrm{K}_{\mathrm{T}}=1.167 \times 10^{-4}$. Weighting factors used in plateau ages are inverse variances. Estimated uncertainties for ages are quoted at one standard deviation.]

\begin{tabular}{|c|c|c|c|c|c|c|c|c|c|}
\hline Step $\left({ }^{\circ} \mathrm{C}\right)$ & $\%{ }^{39} \mathrm{Ar}_{\mathrm{K}}$ & $\%{ }^{40} \mathrm{Ar}_{\mathrm{rad}}$ & $\%{ }^{36} \mathrm{Ar}_{\mathrm{Ca}}$ & ${ }^{40} \mathrm{Ar} /{ }^{39} \mathrm{Ar}$ & ${ }^{37} \mathrm{Ar} /{ }^{39} \mathrm{Ar}$ & ${ }^{36} \mathrm{Ar} /{ }^{39} \mathrm{Ar}$ & $\mathrm{K} / \mathrm{Ca}$ & $\mathrm{Cl} / \mathrm{K}$ & Age (Ma) \\
\hline Sample A & \multicolumn{2}{|c|}{$B A S A L T$} & \multicolumn{2}{|c|}{$J=0.00347452$} & & & & & \\
\hline 550 & 1.16 & 33.97 & 1.91 & 9.1028 & 1.4863 & 0.02070 & 0.329 & 0.00524 & $19.300 \pm 0.675$ \\
\hline 625 & 17.58 & 72.16 & 8.17 & 4.1894 & 1.3098 & 0.00426 & 0.374 & 0.00059 & $18.868 \pm 0.091$ \\
\hline 675 & 14.97 & 82.59 & 20.73 & 3.4343 & 1.9601 & 0.00251 & 0.250 & 0.00031 & $17.715 \pm 0.084$ \\
\hline 725 & 14.45 & 80.91 & 28.73 & 3.4391 & 3.3216 & 0.00308 & 0.147 & 0.00037 & $17.396 \pm 0.087$ \\
\hline 800 & 16.06 & 71.89 & 24.39 & 3.8575 & 4.4144 & 0.00481 & 0.111 & 0.00042 & $17.350 \pm 0.150$ \\
\hline 875 & 10.82 & 81.85 & 33.18 & 3.4827 & 3.9386 & 0.00316 & 0.124 & 0.00094 & $17.826 \pm 0.202$ \\
\hline 950 & 8.57 & 86.45 & 31.03 & 3.2714 & 2.4858 & 0.00213 & 0.197 & 0.00158 & $17.670 \pm 0.247$ \\
\hline 1025 & 7.34 & 77.98 & 17.39 & 3.6691 & 2.1395 & 0.00327 & 0.229 & 0.00178 & $17.871 \pm 0.288$ \\
\hline 1100 & 4.87 & 63.84 & 23.17 & 6.1131 & 8.4490 & 0.00970 & 0.058 & 0.04183 & $24.436 \pm 0.283$ \\
\hline 1175 & 3.15 & 56.62 & 41.78 & 9.8367 & 38.8757 & 0.02475 & 0.012 & 0.00430 & $35.507 \pm 0.497$ \\
\hline \multirow[t]{3}{*}{1250} & 1.04 & 83.37 & 25.11 & 38.3110 & 27.1438 & 0.02875 & 0.018 & 0.00541 & $193.238 \pm 1.26$ \\
\hline & & & & & \multicolumn{2}{|c|}{ Total gas age $(\mathrm{Ma})$} & & & $20.7 \pm 0.6$ \\
\hline & & & & & \multicolumn{2}{|c|}{ Best estimate age (Ma) } & & & $17.38 \pm 0.12$ \\
\hline Sample B & \multicolumn{2}{|c|}{$B A S A L T$} & \multicolumn{2}{|l|}{$J=0.0034999$} & & & & & \\
\hline 550 & 0.40 & 10.07 & 4.44 & 16.2609 & 8.6469 & 0.05176 & 0.056 & 0.04745 & $10.372 \pm 2.403$ \\
\hline 625 & 7.21 & 47.65 & 13.27 & 6.8517 & 6.9633 & 0.01396 & 0.070 & 0.00846 & $20.593 \pm 0.193$ \\
\hline 700 & 10.86 & 60.04 & 22.98 & 4.8298 & 7.2918 & 0.00844 & 0.067 & 0.00390 & $18.305 \pm 0.137$ \\
\hline 775 & 23.67 & 62.93 & 27.79 & 4.3721 & 7.8950 & 0.00756 & 0.062 & 0.00198 & $17.380 \pm 0.107$ \\
\hline 850 & 22.13 & 74.66 & 33.20 & 3.7614 & 5.9711 & 0.00478 & 0.082 & 0.00144 & $17.716 \pm 0.142$ \\
\hline 925 & 13.98 & 80.77 & 32.03 & 4.0611 & 4.6288 & 0.00384 & 0.106 & 0.00295 & $20.657 \pm 0.201$ \\
\hline 1000 & 7.77 & 67.99 & 25.47 & 4.5849 & 6.3429 & 0.00662 & 0.077 & 0.00500 & $19.661 \pm 0.344$ \\
\hline 1050 & 3.34 & 55.59 & 25.15 & 5.3471 & 10.1119 & 0.01070 & 0.048 & 0.13733 & $18.800 \pm 0.778$ \\
\hline 1100 & 4.46 & 54.09 & 57.13 & 4.7204 & 36.6029 & 0.01704 & 0.013 & 0.02758 & $16.456 \pm 0.327$ \\
\hline 1150 & 3.58 & 45.90 & 66.45 & 5.9552 & 80.9584 & 0.03241 & 0.006 & 0.00283 & $18.174 \pm 0.598$ \\
\hline 1225 & 1.65 & 38.23 & 39.42 & 11.1633 & 57.0086 & 0.03847 & 0.008 & 0.00229 & $27.814 \pm 0.716$ \\
\hline \multirow[t]{3}{*}{1350} & 0.95 & 34.63 & 33.16 & 13.9501 & 57.5019 & 0.04613 & 0.008 & 0.00237 & $31.464 \pm 1.097$ \\
\hline & & & & & \multicolumn{2}{|c|}{ Total gas age (Ma) } & & & $18.7 \pm 0.6$ \\
\hline & & & & & \multicolumn{2}{|c|}{ Best estimate age (Ma) } & & & $17.38 \pm 0.11$ \\
\hline Sample C & \multicolumn{2}{|c|}{$B A S A L T$} & \multicolumn{2}{|c|}{$J=0.00428292$} & & & & & \\
\hline 550 & 1.18 & 7.73 & 0.80 & 26.9330 & 2.5572 & 0.08475 & 0.191 & 0.00672 & $16.050 \pm 1.475$ \\
\hline 625 & 16.84 & 17.76 & 2.22 & 13.2268 & 3.1399 & 0.03762 & 0.156 & 0.00368 & $18.095 \pm 0.383$ \\
\hline 675 & 14.74 & 22.79 & 5.02 & 10.3429 & 5.3682 & 0.02842 & 0.091 & 0.00370 & $18.184 \pm 0.298$ \\
\hline 725 & 11.70 & 23.13 & 8.58 & 10.3955 & 9.5367 & 0.02955 & 0.051 & 0.00415 & $18.601 \pm 0.450$ \\
\hline 800 & 12.23 & 23.53 & 14.11 & 9.9805 & 15.9346 & 0.03004 & 0.030 & 0.00468 & $18.252 \pm 0.445$ \\
\hline 875 & 10.45 & 37.61 & 29.28 & 5.8915 & 19.3102 & 0.01755 & 0.025 & 0.00861 & $17.266 \pm 0.449$ \\
\hline 950 & 8.13 & 50.57 & 35.18 & 6.3460 & 21.5947 & 0.01633 & 0.022 & 0.01737 & $24.993 \pm 0.555$ \\
\hline 1025 & 5.69 & 58.25 & 32.25 & 8.5420 & 21.5511 & 0.01777 & 0.022 & 0.02564 & $38.597 \pm 0.509$ \\
\hline 1100 & 4.59 & 39.39 & 31.74 & 7.9205 & 28.3529 & 0.02376 & 0.017 & 0.02241 & $24.414 \pm 0.623$ \\
\hline 1200 & 7.59 & 38.55 & 73.90 & 4.6799 & 103.3040 & 0.03718 & 0.004 & 0.01196 & $14.931 \pm 0.899$ \\
\hline \multirow[t]{3}{*}{1400} & 6.86 & 58.44 & 76.99 & 3.7052 & 65.1977 & 0.02252 & 0.007 & 0.00890 & $17.423 \pm 0.632$ \\
\hline & & & & & \multicolumn{2}{|c|}{ Total gas age (Ma) } & & & $19.8 \pm 0.6$ \\
\hline & & & & & Best estima & age (Ma) & & & $17.27 \pm 0.45$ \\
\hline Sample GV & & PLAGIO & $C L A S E$ & $J=0.0028$ & 171 & & & & \\
\hline 550 & 0.04 & -4.17 & 1.07 & 97.1568 & 13.9450 & 0.34648 & 0.035 & 0.17788 & $-21.44 \pm 101.09$ \\
\hline 625 & 1.16 & 23.53 & 12.03 & 15.1367 & 20.1195 & 0.04449 & 0.024 & 0.13096 & $18.712 \pm 2.974$ \\
\hline 700 & 4.47 & 31.98 & 23.36 & 8.5628 & 22.5469 & 0.02568 & 0.021 & 0.04133 & $14.428 \pm 0.459$ \\
\hline 775 & 9.32 & 45.62 & 35.12 & 6.5957 & 24.6361 & 0.01866 & 0.020 & 0.00242 & $15.870 \pm 0.263$ \\
\hline 840 & 11.35 & 55.91 & 46.96 & 5.3713 & 26.5779 & 0.01505 & 0.018 & 0.00008 & $15.860 \pm 0.232$ \\
\hline 910 & 13.55 & 60.89 & 55.76 & 4.5610 & 28.4698 & 0.01358 & 0.017 & 0.00015 & $14.691 \pm 0.215$ \\
\hline 980 & 14.91 & 66.83 & 63.43 & 4.3452 & 31.6175 & 0.01326 & 0.015 & 0.00013 & $15.392 \pm 0.217$ \\
\hline 1050 & 15.11 & 63.18 & 62.65 & 4.4523 & 34.8033 & 0.01478 & 0.014 & 0.00028 & $14.945 \pm 0.230$ \\
\hline 1120 & 12.72 & 66.25 & 66.57 & 4.3538 & 37.0124 & 0.01479 & 0.013 & 0.00027 & $15.346 \pm 0.251$ \\
\hline 1200 & 8.13 & 59.41 & 59.31 & 4.7674 & 35.7269 & 0.01602 & 0.013 & 0.00056 & $15.057 \pm 0.305$ \\
\hline 1300 & 3.82 & 49.55 & 47.26 & 6.2403 & 35.7881 & 0.02014 & 0.013 & 0.00182 & $16.434 \pm 0.533$ \\
\hline 1400 & 5.43 & 61.14 & 59.85 & 5.0727 & 37.2214 & 0.01654 & 0.013 & 0.00179 & $16.499 \pm 0.402$ \\
\hline & & & & & Total gas a & (Ma) & & & $15.4 \pm 0.5$ \\
\hline & & & & & Plateau age & & & & $15.08 \pm 0.11$ \\
\hline & & & & & Isochron ag & Ma) & & & $15.0 \pm 2.2$ \\
\hline
\end{tabular}


Table 3.- Incremental heating ${ }^{40} \mathrm{Ar} /{ }^{39} \mathrm{Ar}$ ages of volcanic rocks of the Topanga Formation (Hoots, 1931) from the eastern Santa Monica Mountains and Glendora Volcanics, California-Continued.

\begin{tabular}{|c|c|c|c|c|c|c|c|c|c|}
\hline Step $\left({ }^{\circ} \mathrm{C}\right)$ & $\%{ }^{39} \mathrm{Ar}_{\mathrm{K}}$ & $\%{ }^{40} \mathrm{Ar}_{\mathrm{rad}}$ & $\%{ }^{36} \mathrm{Ar}_{\mathrm{Ca}}$ & ${ }^{40} \mathrm{Ar} /{ }^{39} \mathrm{Ar}$ & ${ }^{37} \mathrm{Ar} /{ }^{39} \mathrm{Ar}$ & ${ }^{36} \mathrm{Ar} /{ }^{39} \mathrm{Ar}$ & $\mathrm{K} / \mathrm{Ca}$ & $\mathrm{Cl} / \mathrm{K}$ & Age (Ma) \\
\hline \multicolumn{2}{|c|}{ Sample GV-12 } & \multicolumn{2}{|c|}{ PLAGIOCLASE } & \multicolumn{2}{|c|}{$J=0.00286171$} & & & & \\
\hline 550 & 0.13 & 7.90 & 4.28 & 27.7167 & 14.5005 & 0.0902 & 0.033 & 0.00103 & $11.375 \pm 35.24$ \\
\hline 625 & 1.94 & 17.33 & 14.32 & 14.7210 & 25.8624 & 0.0480 & 0.019 & 0.00247 & $13.353 \pm 2.436$ \\
\hline 700 & 5.67 & 34.49 & 31.00 & 8.7448 & 32.7033 & 0.0281 & 0.015 & 0.00041 & $15.853 \pm 0.855$ \\
\hline 775 & 9.20 & 41.14 & 42.55 & 6.8848 & 38.1111 & 0.0238 & 0.013 & 0.00026 & $14.948 \pm 0.558$ \\
\hline 850 & 11.71 & 38.59 & 40.90 & 7.5199 & 40.5918 & 0.0264 & 0.012 & 0.00014 & $15.340 \pm 0.330$ \\
\hline 925 & 13.92 & 58.97 & 60.80 & 5.1703 & 41.6882 & 0.0182 & 0.011 & 0.00009 & $16.127 \pm 0.294$ \\
\hline 1000 & 16.17 & 63.11 & 66.05 & 4.6679 & 42.4033 & 0.0171 & 0.011 & 0.00015 & $15.592 \pm 0.279$ \\
\hline 1075 & 19.48 & 61.23 & 65.56 & 4.5815 & 42.8049 & 0.0174 & 0.011 & 0.00009 & $14.855 \pm 0.267$ \\
\hline 1150 & 11.10 & 63.57 & 66.20 & 4.6179 & 41.7043 & 0.0168 & 0.011 & 0.00019 & $15.530 \pm 0.322$ \\
\hline 1225 & 5.05 & 57.99 & 60.16 & 5.0528 & 40.6182 & 0.0180 & 0.012 & 0.00065 & $15.489 \pm 0.551$ \\
\hline \multirow[t]{4}{*}{1350} & 5.63 & 53.32 & 52.72 & 5.7784 & 38.1425 & 0.0192 & 0.013 & 0.00200 & $16.255 \pm 0.502$ \\
\hline & & & & & \multicolumn{2}{|c|}{ Total gas age (Ma) } & & & $15.4 \pm 0.5$ \\
\hline & & & & & \multicolumn{2}{|c|}{ Plateau age (Ma) } & & & $15.32 \pm 0.16$ \\
\hline & & & & & \multicolumn{2}{|c|}{ Isochron age (Ma) } & & & $15.45 \pm 0.86$ \\
\hline \multicolumn{2}{|c|}{ Sample GV-17 } & $B A S A L T$ & \multicolumn{2}{|c|}{$J=0.00283602$} & & & & & \\
\hline 550 & 0.26 & 88.60 & 20.42 & 5.4848 & 2.0121 & 0.00262 & 0.243 & 0.000545 & $24.727 \pm 1.908$ \\
\hline 625 & 5.53 & 80.81 & 15.50 & 4.6798 & 2.0747 & 0.00356 & 0.236 & 0.000392 & $19.272 \pm 0.114$ \\
\hline 675 & 12.15 & 94.64 & 43.70 & 3.8888 & 1.9699 & 0.00120 & 0.248 & 0.000177 & $18.757 \pm 0.073$ \\
\hline 710 & 14.97 & 96.58 & 57.93 & 3.6755 & 2.0452 & 0.00094 & 0.239 & 0.000121 & $18.096 \pm 0.066$ \\
\hline 750 & 16.68 & 95.71 & 56.22 & 3.5462 & 2.3410 & 0.00111 & 0.209 & 0.000105 & $17.309 \pm 0.090$ \\
\hline 800 & 17.20 & 94.49 & 34.34 & 3.4551 & 2.7501 & 0.00135 & 0.178 & 0.000205 & $16.657 \pm 0.088$ \\
\hline 850 & 12.40 & 92.53 & 52.54 & 3.4325 & 3.4848 & 0.00176 & 0.140 & 0.000531 & $16.216 \pm 0.110$ \\
\hline 900 & 7.62 & 90.25 & 51.49 & 3.4887 & 4.4756 & 0.00231 & 0.109 & 0.001353 & $16.086 \pm 0.164$ \\
\hline 975 & 5.28 & 86.21 & 42.81 & 3.6797 & 4.7495 & 0.00295 & 0.103 & 0.004193 & $16.209 \pm 0.230$ \\
\hline 1025 & 2.64 & 84.45 & 28.52 & 3.8449 & 2.9898 & 0.00279 & 0.164 & 0.008548 & $16.570 \pm 0.293$ \\
\hline 1100 & 2.02 & 77.92 & 21.99 & 3.9969 & 3.1318 & 0.00379 & 0.156 & 0.011391 & $15.899 \pm 0.380$ \\
\hline 1200 & 1.38 & 68.37 & 40.50 & 4.2992 & 11.6992 & 0.00768 & 0.042 & 0.018019 & $15.094 \pm 0.554$ \\
\hline \multirow[t]{2}{*}{1350} & 1.87 & 77.17 & 41.16 & 3.9664 & 7.9809 & 0.00516 & 0.061 & 0.014009 & $15.676 \pm 0.410$ \\
\hline & & & & & \multicolumn{2}{|c|}{ Total gas age $(\mathrm{Ma})$} & & & $17.2 \pm 0.5$ \\
\hline \multicolumn{2}{|c|}{ Sample GV-18 } & \multicolumn{2}{|c|}{ PLAGIOCLASE } & \multicolumn{2}{|c|}{$J=0.00281499$} & & & & \\
\hline 550 & 0.13 & -20.13 & 5.27 & 18.4204 & 15.6592 & 0.07902 & 0.031 & 0.09520 & $-19.132 \pm 9.20$ \\
\hline 625 & 2.31 & 31.63 & 18.61 & 7.7339 & 15.3580 & 0.02195 & 0.032 & 0.05014 & $12.510 \pm 0.525$ \\
\hline 700 & 6.33 & 61.53 & 42.31 & 4.8072 & 17.1749 & 0.01080 & 0.028 & 0.02033 & $15.135 \pm 0.216$ \\
\hline 775 & 12.53 & 72.19 & 55.29 & 4.1622 & 18.0725 & 0.00870 & 0.027 & 0.00389 & $15.382 \pm 0.145$ \\
\hline 850 & 14.31 & 79.39 & 64.82 & 3.8380 & 18.3372 & 0.00753 & 0.026 & 0.00044 & $15.601 \pm 0.136$ \\
\hline 900 & 12.65 & 80.12 & 67.12 & 3.7220 & 18.9821 & 0.00752 & 0.025 & 0.00013 & $15.278 \pm 0.144$ \\
\hline 950 & 8.99 & 80.64 & 69.08 & 3.6452 & 19.8053 & 0.00763 & 0.024 & 0.00011 & $15.068 \pm 0.172$ \\
\hline 1025 & 11.62 & 78.80 & 67.25 & 3.7451 & 20.5104 & 0.00811 & 0.024 & 0.00015 & $15.135 \pm 0.154$ \\
\hline 1100 & 10.12 & 56.40 & 42.23 & 5.1919 & 20.9695 & 0.01321 & 0.023 & 0.00039 & $15.023 \pm 0.177$ \\
\hline 1175 & 6.99 & 56.77 & 41.16 & 5.1769 & 19.8396 & 0.01282 & 0.024 & 0.00084 & $15.065 \pm 0.210$ \\
\hline 1275 & 4.76 & 64.87 & 50.16 & 4.7068 & 21.0617 & 0.01117 & 0.023 & 0.00135 & $15.661 \pm 0.275$ \\
\hline \multirow[t]{4}{*}{1400} & 9.25 & 71.15 & 59.49 & 4.2073 & 22.5139 & 0.01007 & 0.021 & 0.00165 & $15.373 \pm 0.180$ \\
\hline & & & & & \multicolumn{2}{|c|}{ Total gas age $(\mathrm{Ma})$} & & & $15.2 \pm 0.4$ \\
\hline & & & & & \multicolumn{2}{|c|}{ Plateau age (Ma) } & & & $15.28 \pm 0.05$ \\
\hline & & & & & \multicolumn{2}{|c|}{ Isochron age (Ma) } & & & $15.38 \pm 0.17$ \\
\hline
\end{tabular}

\section{${ }^{40} \mathrm{Ar} /{ }^{39} \mathrm{Ar}$ results from the Glendora Volcanics}

The four samples from the Glendora Volcanics in the eastern San Jose Hills are all from the lower part of the deformed lavas of that area. Samples GV-9, GV-12, and GV-18 (table 3; figs. 6, 7) are porphyritic pyroxene-bearing andesites from which plagioclase was separated for ${ }^{40} \mathrm{Ar} /{ }^{39} \mathrm{Ar}$ incremental heating. The age spectrum of sample GV-9 is irregular, with low- and high-temperature increments yield- ing ages differing significantly from those of intermediate temperature steps at confidence levels greater than 95 percent (fig. 6). The $910^{\circ} \mathrm{C}$ to $1,200^{\circ} \mathrm{C}$ steps satisfy plateau criteria, yielding an age of $15.08 \pm 0.11 \mathrm{Ma}$ for 64.4 percent of the ${ }^{39} \mathrm{Ar}$ released. $\mathrm{Cl} / \mathrm{K}$ values reveal a slightly $\mathrm{U}$-shaped pattern, but ages derived from the steps with higher $\mathrm{Cl} / \mathrm{K}$ are only slightly elevated above the plateau. The plagioclase may contain a small amount of excess ${ }^{40} \mathrm{Ar}$, but the majority of the gas released is consistent with the plateau. The total-gas age of 

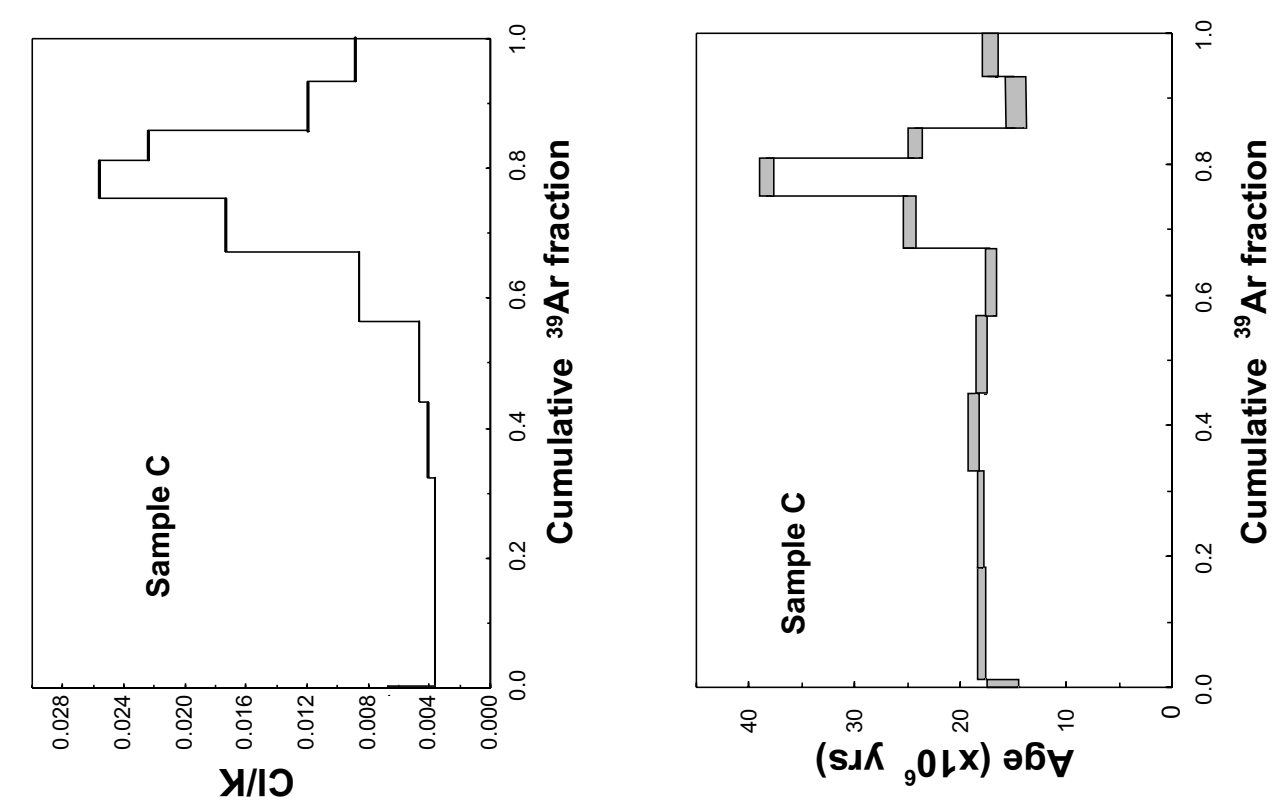

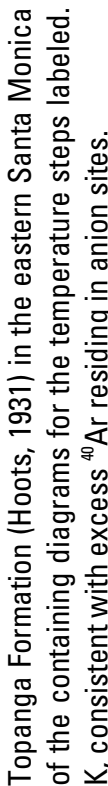
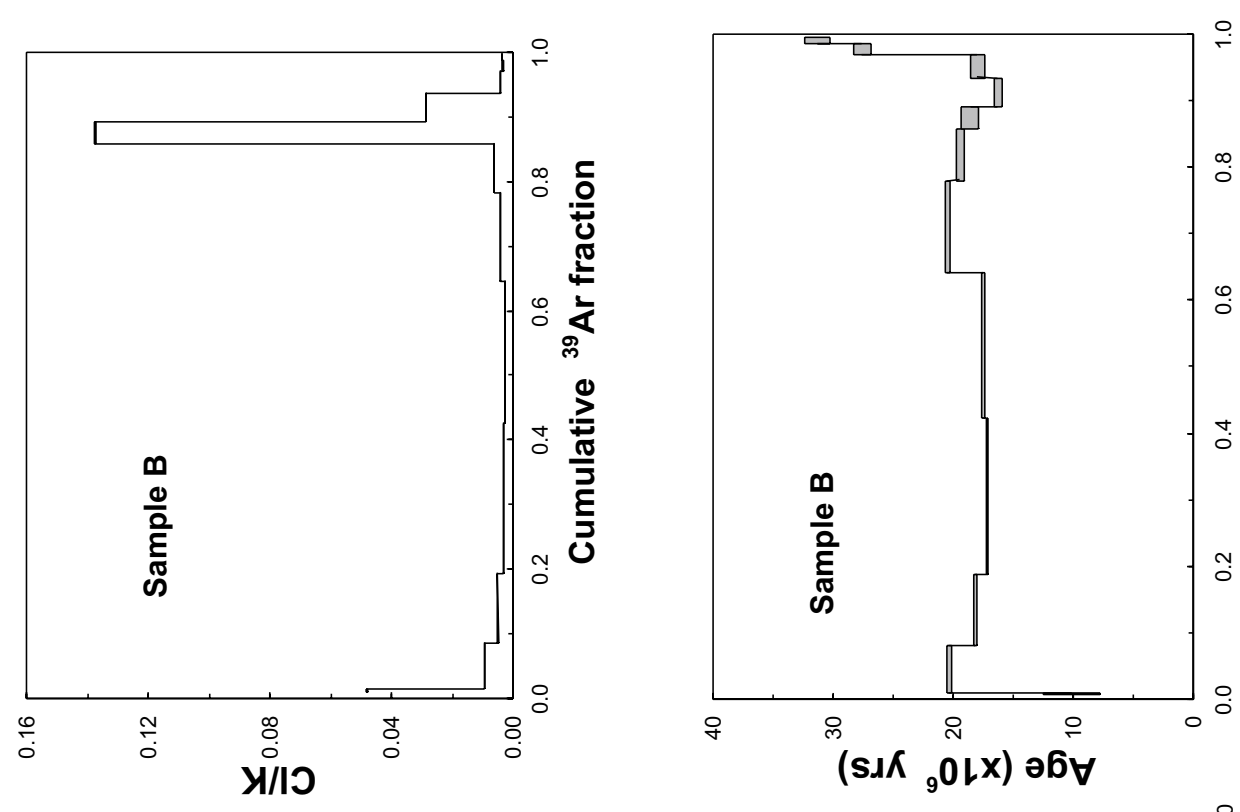

뜬

튼 능 을

Ч里产

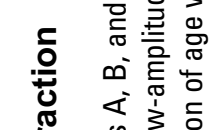

눈 $\frac{6}{2}$ 응 훙

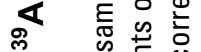

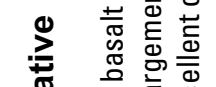

节

ड़

U

Ф) 인

文究

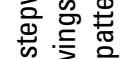

등 흥
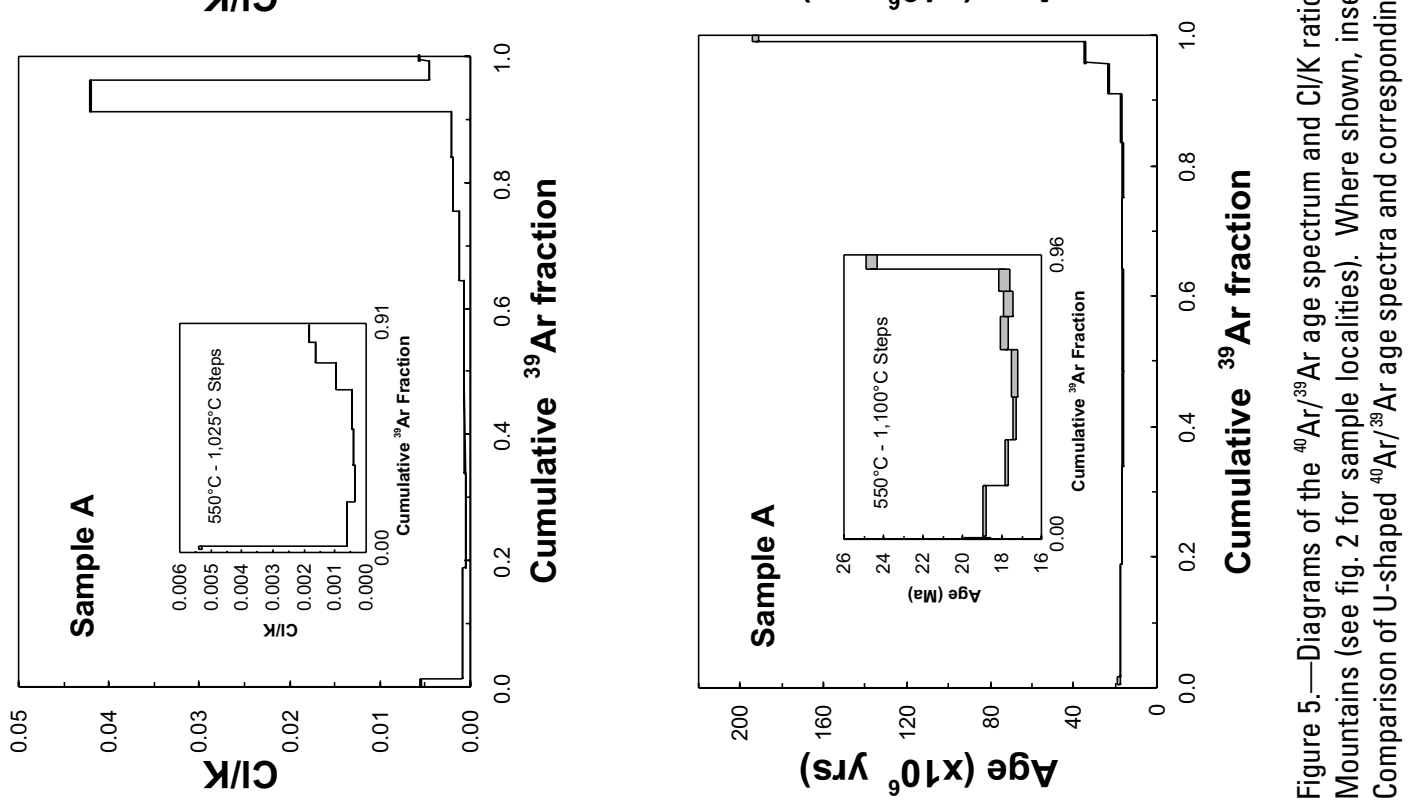

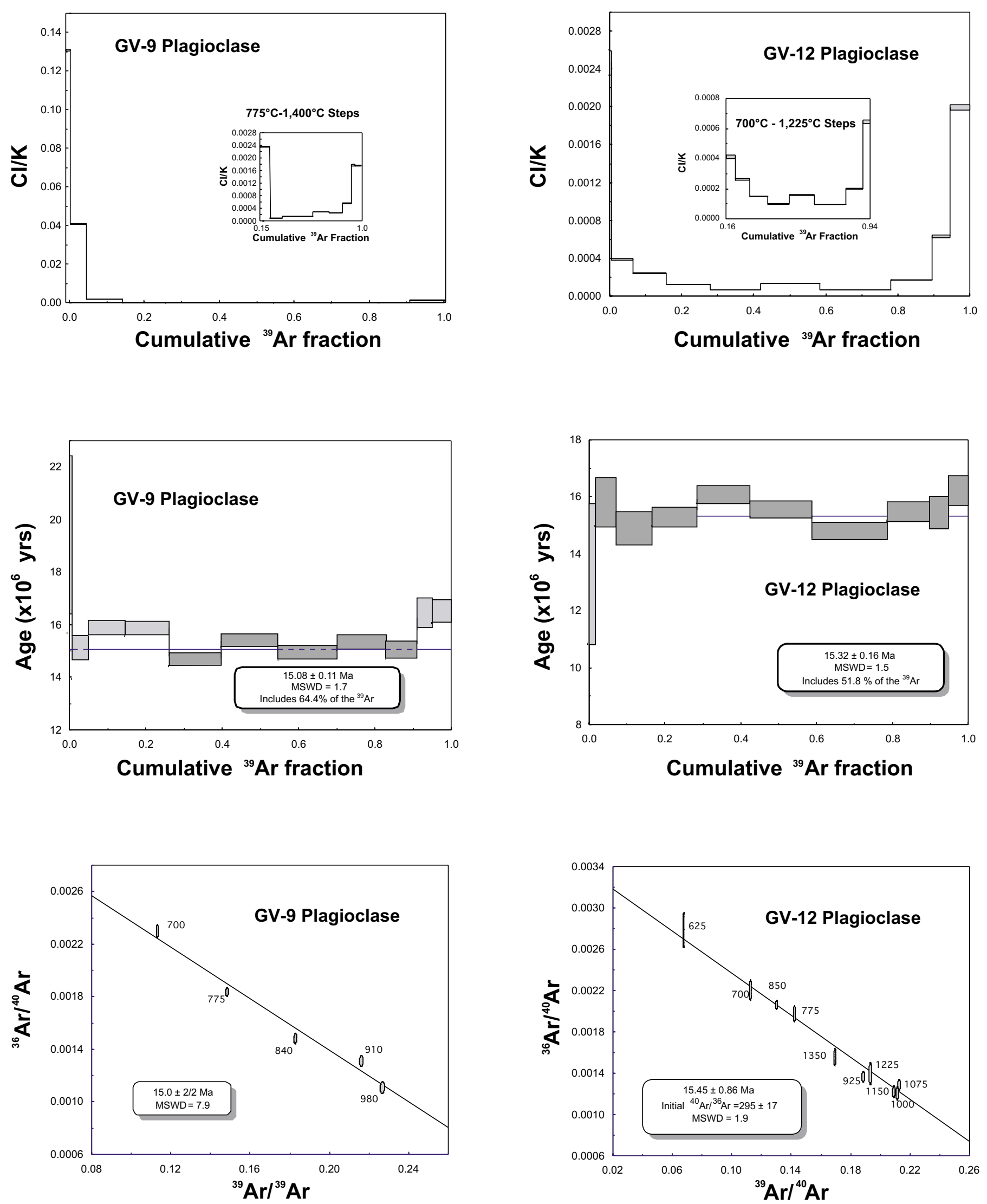

Figure 6.-Diagrams of the ${ }^{40} \mathrm{Ar} /{ }^{39} \mathrm{Ar}$ age spectrum, $\mathrm{Cl} / \mathrm{K}$ ratio, and inverse isochron from stepwise heating of Glendora Volcanics samples GV-9 and GV-12 (see fig. 1 for sample localities). Where shown, inset drawings represent enlargements of low-amplitude portions of the containing diagrams for the temperature steps labeled. Ages are listed in millions of years with \pm of 1 . MSWD, the mean square of weighted deviates (McIntyre and others, 1966), is a measure of the goodness of fit of the data. Samples are from andesites in the lower part of the volcanic sequence. 

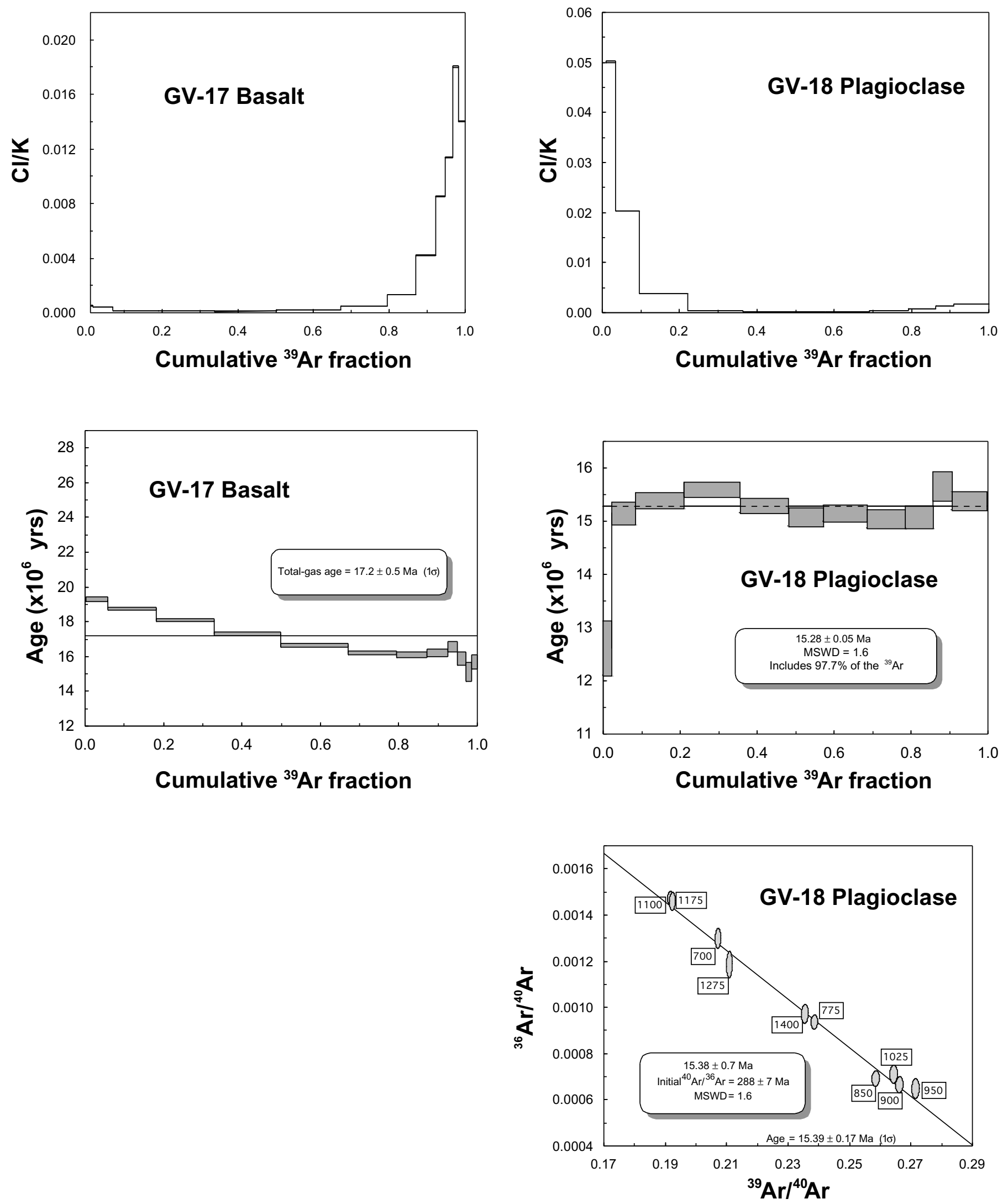

Figure 7.-Diagrams of the ${ }^{40} \mathrm{Ar} /{ }^{39} \mathrm{Ar}$ age spectrum, $\mathrm{Cl} / \mathrm{K}$ ratio, and inverse isochron from stepwise heating of Glendora Volcanics samples GV-17 and GV-18 (see fig. 1 for sample localities). Sample GV-18 is from a stratigraphic position near the base of the volcanic sequence. Sample GV17 is from basalt in fault contact with the andesitic sequence. Parameters are as shown in figure 6. 
$15.4 \pm 0.5 \mathrm{Ma}$, slightly older than the plateau age, is consistent with either a minor component of excess ${ }^{40} \mathrm{Ar}$ or with minor redistribution of ${ }^{40} \mathrm{Ar}$ without loss.

Plagioclase from sample GV-12 (fig. 6) yields a plateau-type age spectrum with an age of 15.32 $\pm 0.16 \mathrm{Ma}$ for the $1,000^{\circ} \mathrm{C}$ to $1,225^{\circ} \mathrm{C}$ steps representing 51.8 percent of the ${ }^{39} \mathrm{Ar}$ released. Only the age difference between the $925^{\circ} \mathrm{C}$ and $1,075^{\circ} \mathrm{C}$ steps prevents recognition of a much broader plateau. Underestimation of the uncertainties in either or both of these steps could be responsible for limiting this plateau. Ages from earlier and later increments differ only slightly above the 95percent level of confidence, consistent with only minor disturbance of the age spectrum, as indicated by the total-gas age of $15.4 \pm 0.5 \mathrm{Ma}$. $\mathrm{Cl} / \mathrm{K}$ ratios for this sample reveal a U-shaped release, but the values are extremely low, consistent with insignificant amounts of excess ${ }^{40} \mathrm{Ar}$.

Plagioclase from sample GV-18 yields a rather imprecise plateau-type age spectrum (fig. 7), with minor complications introduced by scatter greater than accommodated by the estimated analytical errors. Using criteria discussed earlier (Fleck and others, 1977), a plateau age of $15.13 \pm 0.11 \mathrm{Ma}$ is defined by the $900^{\circ} \mathrm{C}$ to $1,175^{\circ} \mathrm{C}$ steps, representing 50.4 percent of the ${ }^{39} \mathrm{Ar}$ released. The remaining steps are excluded because of age differences greater than $2 \sigma$ in the $850^{\circ} \mathrm{C}$ and $1,275^{\circ} \mathrm{C}$ steps. Criteria of Ludwig (2001), which do not require concordance between all gas fractions of a plateau, would define a plateau age of $15.28 \pm 0.05 \mathrm{Ma}$ using all but the $550^{\circ} \mathrm{C}$ and $625^{\circ} \mathrm{C}$ steps. Those two steps indicate minor loss of ${ }^{40} \mathrm{Ar}$ under either set of criteria. An MSWD (McIntyre and others, 1966) of 0.35 for the $900^{\circ} \mathrm{C}$ to $1,175^{\circ} \mathrm{C}$ plateau age compares to an MSWD of 1.6 using all steps except $550^{\circ} \mathrm{C}$ and $625^{\circ} \mathrm{C}$, indicative of the increased scatter related to the additional points. The ages are not different statistically at levels of confidence above 80 percent, however, nor are they different from the total-gas age of 15.2 $\pm 0.4 \mathrm{Ma}$. Considering this total-gas age and clear evidence for minor Ar loss in the first two steps, the probability of minor internal redistribution of ${ }^{40} \mathrm{Ar}$ prompts us to use the larger plateau designation with an age of $15.28 \pm 0.05 \mathrm{Ma}$.

Sample GV-17, a finely crystalline, iddingsite-bearing basalt, was collected from a sequence of basalt, sandstone, and conglomerate separated from adjacent andesites by faulting. Results of incremental heating of a 45-to-60-mesh wholerock aliquant of this sample reveal a continuously decreasing age spectrum (fig. 7). The total-gas age from this experiment is $17.2 \pm 0.5 \mathrm{Ma}$, but the ages range from an initial step of 24.7 Ma to about $15.1 \mathrm{Ma}$ at $1,200^{\circ} \mathrm{C}$ (table 1 ). Turner and Cadogan (1974) provided an understanding of this type of age spectrum from their study of fine-grained lunar materials. The spectrum is produced by loss of potassium-derived ${ }^{39} \mathrm{Ar}$ from near-surface lattice sites of potassium-bearing phases. Their results, confirmed by experiments of Huneke and Smith (1976), showed that ${ }^{39} \mathrm{Ar}$ would be depleted in a surface layer $0.08 \mu \mathrm{m}$ thick on neutron-irradiated grains as a result of recoil of the ${ }^{39}$ Ar nucleus following the $\left.{ }^{39} \mathrm{~K}(\mathrm{n}, \mathrm{p})\right)^{39}$ Ar reaction. Surface-to-volume ratios show that recoil loss of ${ }^{39} \mathrm{Ar}$ from grains larger than about $100 \mu \mathrm{m}$ is generally unimportant. Basalts with fine-grained groundmass grains considerably less than
$100 \mu \mathrm{m}$ in diameter, however, may exhibit substantial effects from recoil (Turner and Cadogan, 1974; Huneke and Smith, 1976; Fleck and others, 1977). The more or less monotonically declining ages observed in the age spectrum of sample $\mathrm{GV}-17$ are a result typical of ${ }^{39} \mathrm{Ar}$ recoil. Interpretation of this age spectrum, however, depends critically on whether ${ }^{39} \mathrm{Ar}$ was lost completely from the basalt grains or if it recoiled from a less retentive phase, such as groundmass plagioclase, into a more retentive phase like groundmass pyroxene. In the first case, involving bulk loss of ${ }^{39} \mathrm{Ar}$ from the rock, the ages of the highest temperature grain-core-dominated increments may approach the true age of the rock, but lower-temperature, grain-surface-dominated fractions are too old because of greater loss of ${ }^{39} \mathrm{Ar}$. Alternatively, no net loss of ${ }^{39} \mathrm{Ar}$ may have occurred, but the redistribution of ${ }^{39} \mathrm{Ar}$ from less retentive to more retentive phases would result in low-temperature increments yielding ages older than the true age and high-temperature increments yielding ages that are too young. In the first case the total-gas age would be erroneously old, whereas in the latter case it would approximate the true age. Because ages of the high-temperature fractions in the basalt sample GV17 approximate the age of the andesite samples, total loss of recoil-liberated ${ }^{39} \mathrm{Ar}$ would explain the difference in apparent age.

\section{${ }^{87} \mathrm{Sr} /{ }^{86} \mathrm{Sr}$ Dating Method and Techniques}

The variation of ${ }^{87} \mathrm{Sr} /{ }^{86} \mathrm{Sr}$ in seawater can be used to determine the age of deposition of a variety of marine fossils, rocks, and minerals (Veizer and others, 1997; McArthur and others, 2001). The precision of an age assignment is dependent on the isotope measurement error, the curve definition, and the slope of the ${ }^{87} \mathrm{Sr} /{ }^{86} \mathrm{Sr}$ variation curve with time. Age assignments are more precise for periods of rapid change in the seawater ${ }^{87} \mathrm{Sr} /{ }^{86} \mathrm{Sr}$ (higher curve slopes). Larger errors are inherent during times of slow change (lower curve slopes). The definition of seawater variation is best in the Cenozoic because of numerous measurements on high quality samples with precise paleontologic age assignments. This, coupled with a steep curve slope between $35 \mathrm{Ma}$ and $15 \mathrm{Ma}$, make the Oligocene and older Miocene ideal for the application of strontium isotope stratigraphy.

In order to be useful in stratigraphic studies, marine fossil carbonate samples must carry their original seawater ${ }^{87} \mathrm{Sr} /{ }^{86} \mathrm{Sr}$ ratios. Fossil carbonates yield spurious $\mathrm{Sr}$ isotope ratios only if they grew in waters poorly mixed with open marine water, or if their ratios were altered during post-burial diagenesis. Shell material that was originally low magnesium calcite is more resistant to diagenesis than shell material of aragonite. Shell appearance is crucial in the field selection process. Specifically, among Miocene fossils, foliated translucent layers of oyster shell and foliated pecten shell are most likely to have retained their original ${ }^{87} \mathrm{Sr} /{ }^{86} \mathrm{Sr}$ ratios.

During diagenesis of carbonates, manganese and iron increase and strontium decreases (see, for example, Brand and Veizer, 1980). Strontium imported in pore fluids com- 
monly evicts and replaces original strontium. Limestones with the lowest $\mathrm{Fe}$ and $\mathrm{Mn}$ and the highest $\mathrm{Sr} / \mathrm{Mn}$ ratios have been shown to be the most likely to retain the original strontium isotope ratio of the seawater (Denison and others, 1994). Trace element analysis has therefore proven useful to evaluate $\mathrm{Sr}$ retention in shell material (for example, Jones and others, 1994; McArthur and others, 2000). Imported stron-

tium may have a ratio either higher or lower than the original strontium, depending on the origin of the imported strontium. A sample may have undergone profound diagenesis and yet appear to retain the original seawater ratio if the strontium imported during alteration has an isotope ratio indistinguishable from the original. Consistency and agreement of results from stratigraphically related samples are marks of a retained marine ratio.

Nine shell samples selected for analysis (see table 2) were crushed, washed and sieved. The cleanest and freshest fragments were picked for analysis. These were taken into solution with $1 \mathrm{~N}$ acetic acid. A portion of the soluble carbonate was prepared for ICP analysis and the remainder used for separation with a Sr-specific resin. The contents of the trace elements $\mathrm{Mn}, \mathrm{Fe}$, and $\mathrm{Sr}$ were determined using a Perkin Elmer Optima 3300DV plasma emission spectrophotometer. The isotope ratios were measured on a second order, double focusing mass spectrometer having a magnetic sector of $60^{\circ}$ with a 13 -inch $(33.0 \mathrm{~cm})$ radius of curvature and an electric sector of $91^{\circ}$ with a 15.8 -inch $(40.1 \mathrm{~cm})$ radius of curvature. Isotopes of mass $85,86,87$, and 88 were measured simultaneously in four separate faraday cups. The ${ }^{87} \mathrm{Sr} /{ }^{86} \mathrm{Sr}$ values were normalized to ${ }^{86} \mathrm{Sr} /{ }^{88} \mathrm{Sr}=0.1194$. The isotope ratios of the unknown samples were measured by comparison to a standard (Burke and Hetherington, 1984). The standard used in most of the measurements was NBS/987, for which a value of 0.710240 has been assumed.

More than 100 measurements of modern seawater yield a weighted mean of $0.709173 \pm 3$. To assign ages from the lookup table, we normalized our results to the modern seawater value of 0.709175 (McArthur and others, 2001). Results of strontium isotopic analyses of fossils from nine localities of the study area are summarized in table 2 . 